\title{
İpek Yolu'ndaki Kültürel Mirasın Dünya Turizmine Kazandırılması: Kazakistan Örneği ${ }^{1}$
}

\author{
Dr. Öğr. Üyesi Muharrem AVCI \\ Kastamonu Üniversitesi Turizm Fakültesi \\ mavci@kastamonu.edu.tr \\ https://orcid.org/0000-0002-0264-1181 \\ Bilim Uzmanı Karlygash SARTAYEVA \\ Kastamonu Üniversitesi Sosyal Bilimler Enstitüsü \\ karlygash_sartaeva@mail.ru \\ https://orcid.org/0000-0001-5096-8368 \\ https://doi.org/10.37847/tdtad.748306
}

\section{Özet}

Bu çalışmada, İpek Yolu'nun Atlas Okyanusu'ndan Çin'e, Avrupa'dan Asya'ya uzanan, sadece ortaçağ dönemindeki eski bir ticaret aracı olmadığı, Batı ve Doğu kültürleri arasında etkileşim köprüsü olduğu tespit edilmiştir. Güncel dünya için ise; ekonomik, kültürel ve siyasi açıdan büyük önem arz ettiği gözlemlenmiştir. Bu durumdan hareketle, bu ticaret yolunun barış eksenli olarak mevcut kültürel mirasın turizm açısından değerlendirilip değerlendirilemeyeceğine ilişkin Kazakistan örneği üzerinde yürütülen bir araştırma gerçekleştirilmiştir. Araştırmanın amacı, Kazakistan'dan geçen İpek Yolu güzergâhları üzerindeki kültürel mirasın yerel halk tarafindan bilinirliğini ve turizm amaçlı kullanıma ilişkin farkındalık düzeyini ölçmektir. Önemi ise, bu kültürel değerlerin uluslararası turizme kazandırılmasını sağlamaya katkıda bulunmaktır. Çalışmada Kazakistan'daki İpek Yolu kültürel değerlerinin ülke turizminin gelişmesine katkısı konusunda, uzmanların ve yerli halkın görüşlerine başvurulmuş, nitel ve nicel alan araştırmaları ve analizleri yapılmıștır. Bu kapsamda, Ulu İpek Yolu konusunda çalışmalar yürüten 11 ilgili uzmana görüşme formu ve İpek Yolu üzerindeki Taraz șehri halkına da nüfustan elde edilen bir örneklem çerçevesinde 400 adet anket uygulaması yapılmıştır. Görüşme formu bulguları tablolar halinde betimlenmiş, doldurulan anket formları ise frekans, T Test, ANOVA istatistikleri ile açıklanmıştır. Sonuç olarak, gerek uzmanların gerekse yerli halkın İpekyolu üzerindeki kültürel mirasın uluslararası turizme kazandırılması konusunda bilinçli ve istekli olduğu tespit edilmiştir.

Anahtar Kelimeler: Ulu İpek Yolu, Kazakistan, Dünya Turizmi, Kültürel Miras.

\section{The Recovery of the Cultural Heritage on the Silk Road to the World Tourism: Kazakhstan Sample}

\begin{abstract}
In this study, it has been determined that the Silk Road is not only an ancient medieval trade tool extending from the Atlantic Ocean to China, from Europe to Asia, but also a bridge of interaction between Western and Eastern cultures. For the current world; It has been observed that it is of great

${ }^{1}$ Bu makale 13-15 Haziran 2019 tarihlerinde Kazakistan'ın Taraz Şehrinde düzenlenen "5. Uluslararası Türk Dünyası Turizm Sempozyumu”nda sunulan ve bildiriler kitabında yer alan bildirinin geliştirilmiş halidir.
\end{abstract}

July-2020 Vol:5 No:1 International Journal of Turkic World Tourism Studies 
economic, cultural and political importance. Based on this situation, a study was carried out on the example of Kazakhstan on whether this trade route could be evaluated in terms of tourism in terms of tourism. The aim of the research is to measure the awareness of the cultural heritage on the Silk Road routes passing through Kazakhstan by the locals and the level of awareness regarding the use of tourism. Its importance is to contribute to ensuring that these cultural values are brought to international tourism. In the study, the opinions of experts and local people were taken, and qualitative and quantitative field researches and analyses were made on "The Contribution of Silk Road Cultural Values in Kazakhstan to the Development of Country Tourism". In this context, 400 questionnaires were applied to 11 relevant experts carrying out studies on the Great Silk Road and a sample of the population from the population of Taraz city on the Silk Road. The interview form findings are described in tables, and the filled questionnaire forms are explained with frequency, $\mathrm{T}$ Test and ANOVA statistics. As a result, it has been determined that both experts and locals are conscious and willing to bring cultural heritage on the Silk Road to international tourism.

Keywords: Great Silk Road, Kazakhstan, World Tourism, Cultural Heritage.

\section{Giriș}

Bu çalışmada, İnsanlık ve iktisat tarihinin en eski kurumsal yapılarından biri ve en önemlisi olan İpek Yolu; dünü, bugünü ve yarınıyla Kazakistan örneğinde ele alınmaktadır. $\mathrm{Bu}$ kapsamda, Kazakistan'dan geçen İpek yolu güzergâhları üzerindeki kültürel mirasların yerli halk tarafindan önemsenmesi ve turizm amaçlı kullanıma ilişkin farkındalık düzeyinin ne olduğunun tespit edilmesi, çalışmanın problemini oluşturmaktadır. Araştırmanın temel amacı; İpek Yolu ticaretinin ne ölçüde Kazakistan'ı etkilediğinin ortaya çıkarılması ve İpek Yolu'nun tarihsel gelişiminden itibaren, oluşan kültürel miraslardan, Orta Asya'nın nasıl etkilendiği ile bu etkilerin Kazakistan'ın günümüzdeki uluslararası turizmi için ne tür katkılar sağlayabileceğini incelemektir. Araştırmanın Önemi; Kazakistan, İpek Yolu şehirlerinin dünya kültürüne katkısının sonuçlarını tartışılıp, şu anda uluslararası önemli kervan yolunu tekrardan canlandırmayı arzu etmekte ve ülke turizminin geliştirilmesine de yön vermek istemektedir (Amatbek, 2017: 23-24). Bu açıdan, ülkedeki İpek Yolu boyunca sıralanmış tarihi şehirleri, o şehirlerdeki tarihi-kültürel yapıların farkındalığını geniş kitlere duyurup, bugünkü Kazakistan modern turizm yaklaşımına katkıda bulunmak büyük önem arz etmektedir.

Çalışmada; İpek Yolu'nun Dünya kültürüne, medeniyetine, insanların sosyal hayatına katkısı merak konusu olduğundan; öncelikle, dün çizgisinden hareket edilmiştir; Kazakistan topraklarında İpek Yolu'nun ortaya çıkışı, Kazak topraklarından geçen İpek Yolu güzergâhları, bu yol boyundaki tarihi şehirler ve yerleşim yerleri incelenmiştir. Bu gün ve yarın için ise, somut olan ve somut olmayan kültürel mirasları ile uluslararası turizm ve ticaret projeleri araştırılmaya gayret edilmiştir (Atasoy, 2012: 4-7; Kydyrali, 2014: 361). Çalışmada "Kazakistan'daki İpek Yolu Kültürel Değerlerinin Ülke Turizminin Gelişmesine Katkısı" konusunda, uzmanların ve yerli halkın görüşlerine başvurulmuş, nitel ve nicel alan araştırmaları ve analizleri yapılmıştır. İlgili incelemelere göz atıldığında, İpek Yolu konusunda dünyada ve Türkiye'de, oldukça zengin bir kaynağa ulaşılmaktadır. Ancak, kuramsal çerçeveyi oluşturan bütünü kapsayan bir araştırılmaya ise rastlanmamıştır.

$\mathrm{Bu}$ çalışma, ilk çağlardan günümüze İpek Yolu'nun değerini vurgulamak, özellikle Kazakistan açısından önemini ortaya koymak, İpek Yolu'ndaki şehirlerin birbirleriyle olan etkileşimlerini ve bu yolun günümüzdeki yeni rolünün önemini toplumlara yansıtmak, turizmin; Kazakistan'ın sosyal, kültürel ve ekonomik gelişimine ne kadar katkıda bulunabileceğini göstermek için hazırlanmıştır.

July-2020 Vol:5 No:1 International Journal of Turkic World Tourism Studies 


\section{Kavramsal Çerçeve}

\section{Dün, Bugün ve Yarın Çizgisinde İpek Yolu}

İpek Yolu, tüm dünyada iyi bilinen bir yoldur; 3000 yıllık bir maziye sahiptir. Ulu İpek Yolu olgusu, salt bir ticaret yolundan, devletler ve halklar arası ilişkilerden ibaret değildir, çok daha fazlasıdır. Ulu İpek Yolu "zaman" ve "coğrafya" arasındaki bir bağlantıdır, köprüdür. Bu manada modern Ulu İpek Yolu "zaman" ve "coğrafya" arasındaki iletişimsel durağanlığ 1 ortadan kaldıracak bir niteliği ihtiva etmelidir (Mammadov, 2014: 184).

Ulu İpek Yolu'na ismini veren ürün İpek olsa da, bu yol' da çok çeşitli ürünlerin ticareti yapılmıştır. Bu Yol; Asya'yı Avrupa'ya ve Afrika'ya bağlayan ilk ticaret yolu olmanın ötesinde, bölgede yaşamış kültürlerin ve inançların şu an üzerinde bulunan toplumlara tarihsel ve kültürel bir miras olarak aktarıldığı bir yerdir (Tezer, 2016: 16). 1800 yılına kadar faaliyette olan İpek Yolunun çeşitli kollarına ait en azından 20.000 kilometrelik kısmı, şu an Türk kültürüyle tanışık ve halen bu kültürün yaşandığı topraklardan geçmektedir (Budagov ve Kurbanov, 2017: 69). Bu noktada, Türk kültürlü toplumların İpek yolunda ki konumlanmasına bakıldığında; Altı bağımsız devlette (Türkiye, Azerbaycan, Türkmenistan, Özbekistan, Kırgızistan, Kazakistan), bu devletler dışında Çin ve Rusya gibi ülkelerde özerk bölgelerde yaşayanlar ile İran, Tacikistan, Moğolistan gibi devletlerin içinde kalabalık topluluklar halinde bulunanlardan oluştuğu görülmektedir (Yereli, 2016: 62). Dolayısıyla İpek Yolu, Türk halklarının yeni topraklara yerleşmesine, aralarında bilim ve uygarlığın karşılıklı gelişmesine de büyük etkisi olmuştur (Artuç, 2014: 201). İpek Yolu vasıtasıyla hem küresel ticaret ve uluslararası iş bölümü, hem de İpek Yolu üzerindeki halkların manevi etkileşimi gerçekleşmiştir (Mammadov, 2014: 184).

Batı ve Doğu'yu, barış ve işbirliğini isteyen halkları, birbirine bağlayan bu yol, kültürel ve ekonomik bir köprü işlevi görmüştür. İpek Yolu'nun yeniden gündeme gelmesi, 21.yüzyıl içerisinde medeniyetler arası iletişim için zemin hazırlayarak bir barış umudu doğurmuştur. Bu noktada bir barış endüstrisi olarak bilinen turizme kritik bir sorumluluk, yüklenmektedir (Gülcan, 2016: 113). Doğu ve Batı'nın çatışmacı değil, uzlaşmacı yanını harekete geçirerek toplumların birbirlerini tanımaları, kültürleriyle tanışmaları ve bu sayede de uluslararası huzur ve güvenliğe katkı sağlanabileceği düşünülmektedir (Oktay, 2016: 182).

\section{Kültürel Miras ve Orta Asya (Türkistan)}

Kültürel miras: bir toplumun üyelerine ortak geçmişlerini tanıtan, aralarındaki dayanışma ve birlik duygularını güçlendiren bir hazinedir. İnsanların tarih boyunca biriktirdikleri tecrübelerin kavranmasını, ortak yaşamışlığının sürekliliğini ve geleceğin doğru kurgulanmasını sağlar (Erkal, 1994: 43).

Kültürel miras; kimlikle, kültürel yaşantıyla, tarihle ilgili somut ve soyut değerlerin tümünü kapsar. Bu miraslar; tarihi kentler ve dokular, kültürel peyzajlar, anıtsal yapılar, arkeolojik alanlar gibi somut; dil, gelenek, dans, müzik, ritüeller vb. gibi yașayan ama somut olmayan değerleri de bünyesinde barındırır. İpek yolu, Türk Dünyasının kültürel mirasıdır. Dolayısıyla, somut ve somut olmayan ortak değerleri VII. Asırdan bu yana, İslam medeniyetiyle özdeşleşmiştir. Türk-İslam medeniyetinin somut kültürel miraslar1;

- Cami-mescit ve türbe gibi dinî;

- Han, bedesten, arasta ve çarşı gibi ticarî;

- İmaret, hamam, köprü, su kemeri, çeşme gibi sosyal; 
- Mektep, medrese, tekke-zaviye ve kütüphane gibi eğitim;

- Kale, kule-ocak, burç ve tabyalar gibi askerî yapılardır" (Ayverdi, 1982: 6).

Bu müesseseler; Türk İslam şehir dokusu anlayışı olarak da İpek yolunda hâkimdir. İpek yolunun somut olmayan kültürel mirasları ise; İslam medeniyetinin üç temel sacayağı olan camiler, tekkeler ve medreselerde üretilen bilgiler ile oralarda yetişen insan mirası olan bilgelerdir (Köse 2012, s.11). Öte yandan inançlarından dinlerine, mitolojilerinden efsanelerine, taş işleme sanatından mimarisine kadar pek çok unsur İpek yolu içindeki kültür yolculuğunu ve akrabalığını ortaya koymaktadır. Kırgızistan'da anlatılan Köroğlu efsanesi, Özbekistan'da konuşulan Nasrettin Hoca hikâyeleri, Azerbaycan'da bilinen Dede Korkut masalları bölgedeki hiçbir Türk topluluğuna yabancı gelmemektedir (Atasoy, 2012: 3). Dolayısıyla İpek Yolundaki kültür değerlerinin iyi analiz edilmesi ve bilinmesi çok önemlidir.

Orta Asya kadim uygarlıkların beşiğidir. Çin, Hint, İran, Arap ve Türk kavimlerinin muazzam birikimleri burada toplanmıştır. Dünyaya buradan teknoloji, bilim, felsefe ve dini-mistik öğretiler yayılmıştır. Pek çok çalışmanın, yüzlerce kitap ve makalenin, edebiyatın ve belgesel filmlerin odak noktası olan Ulu İpek Yolu'nun geleceği konusu şimdi birçok uluslararası toplantıların ana odağıdır. Ulu İpek Yolu'nun açılması, uluslararası pazarların açılması gibi konularda yorum yapanlar; jeopolitik ve jeo-stratejik genişlemeler ve gelecek senaryolarını açıklamaktadırlar. Orta Asya'dan Anadolu'ya uzanan Türk Dünyasında kültür turizminin markası İpek Yolu'dur. İpek Yolu Doğu ve Batının arasında bir köprü ve yollar ağıdır. Yapılan araştırmalara göre, İpek Yolunun tek bir yol olmadığ1 ve zamanın şartlarına göre yeni açılan güzergâhlar ile gittikçe uzayan bir yol ağı olduğu tespit edilmektedir. Bu yol ağı genel itibari ile 2 ana koldan ve çok sayıda tali kollardan oluşan bir güzergâha sahiptir (Deniz, 2016: 197).

İpek Yolunun uzun kısmı, içerisinden 4 bağımsız devletin çıktığı eski adıyla Türkistan'dan geçmektedir. $\mathrm{Bu}$ ülkeler; Türkmenistan, Özbekistan, Kırgızistan ve Kazakistan'dır. Coğrafi konumları ise, Orta Asya'dır. İpek Yolu'nda yayılan medeniyet unsurlar1, sadece ticaret ve yol sistemleriyle ilgili değildir. Somut kültürel miraslar konusunda; büyük çoğunluğu Karahanlı, Selçuklu ve diğer Orta Asya Türk devletlerinden kalan; Hanlar, hamamlar, kervansaraylar, medreseler, pazarlar, çarşılar, ibadet haneler, gösterişli türbeler ve bu çerçevede gelişen şehirler "Türk Dünyasının Ortak Mirasıdır" (Turan, 1969: 275) ve İpek Yolu'nun sembolleri durumundadır. Somut olmayan kültürel miraslar ise, Türk-İslam medeniyetinin dünya medeniyetine ve insanllğa kazandırdığı çok zengin inanç ve ilim insan mirasıyla, Türk Halk biliminin ortak değerleridir (Zeybek, 1997: 235). Orta Asya'da Ulu İpek Yolu'nun Orta Çağ' da altın dönemlerini yaşamış olduğu tespit edilmekte; İnanç önderleri olarak Pir-i Türkistan Hoca Ahmet Yesevi, İmam Buhari, İmam Maturidi, Şah-1 Naşibendi; âlimler olarak Kaşgarlı Mahmud, Yusuf Has Hacip, Biruni, İbn-i Sina, Farabi, Ali Kuş̧̧u, Uluğ bey gibi aydınların da, Ulu İpek Yolu'nun Orta Asya'da kurduğu medeniyetin düşünce ve bilim meyveleri olduğu gözlemlenmiştir (Atasoy, 2014: 10-11). Çin, Fars, Hindu, İslam medeniyetlerinin kavşağında yer alan Orta Asyalı aydınlar, bütün bu kaynaklardan beslenerek eserlerini vermişlerdir. Bu kültürel değerlerin uluslararası turizme kazandırılması büyük önem arz etmektedir.

\section{Kazakistan Doğal ve Kültürel Mirasının Turizm Amaçı Değerlendirilmesi ve İleriye Dönük Projelerinin Tespiti}

İpek Yolu'nun tarihi şehirlerine yönelik kazılar devam etmektedir. Bu yol üzerinde gerçekleştirilen kazılarda arkeologların ortak görüşü; İpek Yolu'nun, dünya kültür hayatı için en başarılı, önemli ve benzersiz rota olduğu şeklindedir. Günümüzdeki arkeolojik kazılar ve bilimsel çalışmalar sayesinde 
İpek Yolu ile ilgili birçok yeni kanıtlara ve yerleşim yerlerine ulaşılmaktadır. Örneğin, Kazak topraklarından geçen İpek Yolu ve kollarında; Otırâr, Sâyram, Sığânak, Sâyran, Sozâk, Türkistân, Tarâz vb. birçok tarihi şehir bulunmuştur (Baypakov, 1998: 10). Bu şehirlerin sadece ticari merkez olarak kalmayıp, bilim ve kültür merkezi olduğuna dair tarihi, arkeolojik ve mimari eserler, gün 1şı̆̆ına çıkmıştır (Ablayeva, 2013: 22).

Burada, Türk-İslam Dünyasının ortak değeri Hoca Ahmet Yesevi'in türbesi, 1993 y1lında Türkiye Cumhuriyeti tarafından restore edilmiş olup 1993 yılını UNESCO, Ahmed Yesevi Yılı' ilan etmiştir. 2000 yılında da Ahmet Yesevi türbesinin bulunduğu Türkistan şehrinin 1500. kuruluş yıl dönemi kutlanmıştır. 13 Temmuz 2002 yılında ise Ahmet Yesevi türbesi, UNESCO Dünya mirası listesine girmiştir (Yesevi, 2010: 23). TÜRKSOY (Uluslararası Kültürü Teşkilatı) Daimi Konseyi, 2012 yılı Astana'dan sonra 2017 yılında Türk Dünyası Kültür Başkenti olarak Kazakistan'ın Türkistan kentini seçmiştir (Purtaş, 2018: 59). Tüm bu çalışmalar, Kazakistan'ı kültürel turizm odağına yerleştirmiş olup İpek Yolu üzerinde yapılan mega projelerle de uluslararası turizme hazırlanmış bulunmaktadır.

Çalışmanın bugünü ve geleceği konusunda; Kazakistan'da turizmin gelişiminde İpek Yolu'na verilen önem dikkat çekmektedir. Bugünkü İpek Yolu üzerindeki ülkelerin siyasi, ekonomik ve kültürel bağlantıları gözden geçirildiğinde bu kapsamda, "Yeni İpek Yolu” Projesi; "UNESCO İpek Yolu Online Platformu" projesi, "TRACECA"(Avrupa, Kafkasya, Asya Ulaştırma Koridoru) , “TRACECA-KEI”" projeleri; “İpek Yolu' nun Otobanlaştırılması" projesi; "ALTID”(Asya Kara Taşımacılığı Altyapısının Geliştirilmesi) projesi; “OBOR”(Bir Kuşak Bir Yol) Çin'e ait proje; TÜRKSOY ve "TWESCO” (Uluslararası Türk Akademisi) vb. projelerin yavaş yavaş hayata geçirilmeye başlandığı, görülmektedir. Ayrıca, küreselleşme sürecinde İpek Yolu'nun yeniden işlevlendirilmesi, Kazakistan'da turizmin gelişmesinde Ulu İpek Yolu'nun rolü; "Kazakistan 2030 Programı"; "Kazakistan, Gezegenin İlk Uzay Noktası" projesi; "Baykonur" uzay üssü, Baykonur'da turistik paket turlar (Uspanova, 2017: 36); "EXPO 2017" gibi projeler de gerçekleştirilmektedir. Bunların yanı sıra, devlet turizm politikası olarak, turizm sektöründe küçük ve orta ölçekli işletmeleri teşvik etmektir. Şu an, Kazakistan'ın turizm pazarında 600'den fazla turistik işletmesi hizmet vermektedir (Ablayeva, 2013: 62). Ayrıca, günümüzde İpek Yolu, önemli rolünü turizm sektörüne taşımıștır. Son y1llarda Dünya Turizm Örgütü (DTÖ) tarafından İpek Yolu güzergâhı boyunca turizmin gelişimi ve tanıtımı için birçok faaliyet gerçekleştirilmiştir. Turizm sektörü günümüzde diğer bir dizi sektörün ve sanayinin gelişimine de katkıda bulunduğu için, bu proje birçok ülke ve uluslararası kuruluşlar tarafından da desteklenmiştir. DTÖ 12. Genel Kurul Oturumu, "Yeni Binyıl İçin Dünya Mirasının Korunması" kararını onaylamıştır. Katılımcılar, uluslararası turizmin, kültürel değerlerin karşılıklı zenginleşmesi ve yayılması, medeniyetler arası diyaloğun teşviki konusunda güçlü bir faktör olduğunu dile getirmiştir (Ablayeva, 2013: 88-89).

\section{Yöntem}

Çalışmanın bu bölümünde, Kazakistan'daki İpek Yolu kültürel değerlerinin turizmin gelişmesine katkısı hakkında uzmanlara ve yerli halka yönelik yapılan alan araştırmalarına yer verilmektedir. Araştırmanın modeli ve hipotezleri, çalışma grubu, veri toplama yöntemi, verilerin çözümlenmesinde kullanılan teknikler alt başlıklardır.

\section{Araştırma Modeli ve Hipotezleri}

Araştırmada nitel veri toplama aracı olarak kullanılan görüşme formu, Kazakistan Cumhuriyet'inde görev yapan kişiler üzerinde yapılmıştır. Görüşme formu 16 adet sorudan oluşmaktadır. Bu form bu alanda uzman araştırmacı ve çalışanlardan 11 kişiye uygulanmıştır. Görüşme formunda, 
Kazakistan'daki İpek Yolu kültürel değerlerinin turizmin gelişmesine katkısı hakkında, bu alanda uzman araştırmacı ve çalışanların görüşlerinden yararlanmak amacıyla hazırlanmıştır. Yapılan çalışma, turizm kavramına farklı bir bakış açısı getirmesi açısından önemlidir. Tarihi İpek Yolu geçen ülkeler arasında yeni kültürel bağlantıların canlandırılması konularında katkı yapacağı düşünülmektedir.

Araştırma modelinin test edilmesi için gerekli olan nicel veriler ise anket formu ile toplanmıştır. Bu anket formu Kazakistan'daki Ulu İpek Yolu kültürel değerlerinin turizmin gelişmesine katkısı hakkında yerli halkın görüşlerinin belirlenmesi amacıyla hazırlanmıştır. Anket, Taraz șehrinde (Nüfus; 400.000 Örneklem;400 kişi olarak) yapılmıştır. Ankette 25 soru yer almaktadır. İlk 5 soru demografik sorulardır. Diğer 20 soru ise temel sorulardır. Bu soruların: 1, 2, 3, 5, 6, 7, 8, 9, 10, 12 , 18 numaralıları Ulu İpek Yolu'yla ilgili genel ifadelerdir. Diğer: 4, 11, 13, 14, 15, 16, 17, 19, 20 numaralıları ise, İpek Yolu'nun Kazakistan açısından yeri ve önemiyle ilgilidir. Araştırmada, Kazakistan kültür turizminin etkin gelişimi gerçekleştiğinde, katılımcılarca nasıl algılanacağı ölçülmeye çalışılmıştır. Bu doğrultuda bu anket çalışmasının ana amacı olan "Kazakistan' daki İpek Yolu kültürel değerlerinin turizmin gelişmesine katkısı" "nı belirlemek için 11, 14, 16, 17, 20 numaralı sorular, ikiye ayırarak Pozitif; 11, 14, 16 (sorular) ve Negatif; 17, 20 (sorular) olarak gruplandırılmıştır.

$\mathrm{Bu}$ model çerçevesinde araştırmanın hipotezleri ise şu şekilde belirlenmiştir:

H1: "Araştırmaya katılanların yaşları ile pozitif bakışa ilişkin görüşleri arasında anlamlı bir farklılık vardır".

H2: "Araştırmaya katılanların cinsiyetleri ile pozitif bakışa ilişkin görüşleri arasında anlamlı bir farklilik vardır".

H3: "Araştırmaya katılanların medeni durumu ile pozitif bakışa ilişkin görüşleri arasında anlamlı bir farklılik vardır".

H4: "Araştırmaya katılanların eğitim durumları ile pozitif bakışa ilişkin görüşleri arasında anlamlı bir farkl1l1k vardir".

H5: "Araştırmaya katılanların mesleği ile pozitif bakışa ilişkin görüşleri arasında anlamlı bir farklılık vardır".

H6: "Araştırmaya katılanların yaşları ile negatif bakışa ilişkin görüşleri arasında anlamlı bir farklılık vardır".

H7: "Araştırmaya katılanların cinsiyetleri ile negatif bakışa ilişkin görüşleri arasında anlamlı bir farklılik vardır".

H8: "Araştırmaya katılanların medeni durum ile negatif bakışa ilişkin görüşleri arasında anlamlı bir farkl111k vardır".

H9: "Araştırmaya katılanların eğitim durumları ile negatif bakışa ilişkin görüşleri arasında anlamlı bir farkl1lik vardir".

H10: "Araştırmaya katılanların mesleği ile negatif bakışa ilişkin görüşleri arasında anlamlı bir farklılik vardır". 


\section{Veri Toplama Yöntemi}

Veri toplama sürecinin ilk basamağında, çalışma grubunda yer alan 11 uzman araştırmacı ve çalışanlara görüşmeler yapılarak başlanmıştır. Uzmanlara yapılan görüşmeler 7-24 Şubat 2019 tarihleri arasında yapılmıştır. Görüşmeler, araştırmacı tarafından hazırlanan görüşme formu kullanılarak yapılmıştır. Görüşme formu uygulanması sırasında elde edilen bilgiler, video kayıt cihazı ve not alınarak kayıt altına alınmıştır. Ortalama 20 ile 35 dakika süren görüşme süreçleri boyunca uzmanların en samimi yanıtları vermeleri için uygun atmosferin oluşturulmasına özen gösterilmiştir.

Veri toplama sürecinin ikinci basamağını da, anket uygulaması oluşmaktadır. Ankette 25 soru yer almaktadır. İlk 5'i demografik sorular diğer 20'i ise temel sorulardır. Anket ölçeği olarak 5'li likert ölçeği kullanılmıştır. Ölçeğe göre katılımcıların cevaplarında kullandıkları 1 numaralı seçenek "Kesinlikle Katılmıyorum", 2 numaralı seçenek "Katılmıyorum", 3 numaralı seçenek "Kararsızım", 4 numaralı seçenek "Katılıyorum", 5 numaralı seçenek ise "Kesinlikle Katılıyorum" anlamında kullanılmıştır. Güvenirlik analizi elde ederek, Frekans analizi, araştırma hipotezlerinin analizinde T test ve Anova istatistikleri yapılmıştır.

\section{Evren ve Örneklem}

Araştırmanın evrenini, Kazakistan'daki Taraz şehrindeki yerel halk oluşturmaktadır. Bunun nedeni hem İpek yolu üzerinde olması, hem de V. Uluslararası Türk Dünyası Turizm Sempozyumu'nun bu şehirde gerçekleştirilmesidir. Araştırmanın evrenini meydana getiren ana kitlenin tamamına ulaşmak ve anket yapabilmek pratik açıdan mümkün olamayacağından, örneklem seçme yoluna gidilmiştir. Araştırmanın örneklem seçiminde ise tesadüfi örnekleme yöntemlerinden basit örneklem yöntemi seçilmiştir. Bu yönteme, ana kütle birimlerinin her birine eşit seçilme şansı veren örnekleme yöntemi denir (Sayım, 2017: 194). Seçilecek örneklem sayısı ise evrenin büyüklüğüne göre aşağıdaki formül ile hesaplanmıştır:

$$
\mathrm{n}=\frac{\mathrm{N} \cdot \mathrm{t}^{2} \cdot \mathrm{p} \cdot \mathrm{q}}{\mathrm{d}^{2} \cdot(\mathrm{N}-1)+\mathrm{t}^{2} \cdot \mathrm{p} \cdot \mathrm{q}}
$$

Formülde p ve q değerleri 0.5 olarak alınmıştır. Örneklemin anlamlılık düzeyi (t) 0.05 için 1.96 , örnekleme hatası ise (d) 0.05 olarak alınmıştır. Formüle göre örneklem sayıs1 367 kişi olarak belirlenmiştir. Araştırma için 400 kişiye anket uygulanmıştır.

\section{Bulgular}

Bu bölümde, araştırmanın amacı doğrultusunda Kazakistan'daki İpek Yolu kültürel değerlerinin turizmin gelişmesine katkısı hakkında uzmanların ve halkın görüşlerini tespit ederek, Kazakistan turizmine yeni bir bakış açısı kazandırılıp kazandırılamayacağı incelenmiş olup, Ulu İpek Yolu'nun önceden şimdiye kadar Orta Asya'ya ve Kazakistan modern turizmine etkisini belirlemek amaçlanmıştır. $\mathrm{Bu}$ amaç doğrultusunda görüşme ve anket bulguları bir arada değerlendirilerek benzerlik ve farklılıklar ortaya koyulmaya çalışılmıştır.

\section{Görüşme Analizinden Elde Edilen Bulgular}

Bu araştırmanın nitel yönteminin çalışma grubu; Kazakistan'1n Almatı şehrinde bulunan "Kazakistan Cumhuriyeti Devlet Merkez Müzesi”, "Uluslararası İşletme Üniversitesi”, "Multimedya Geleneksel 
Müzik Merkezi”, "Kazakistan Tarihi Araştırma Merkezi” ve Nur-Sultan şehrinde bulunan "L.Gumilov adındaki Avrasya Ulusal Üniversitesi", Türkistan şehrindeki "Hoca Ahmet Yesevi adındaki Uluslararası Kazak-Türk Üniversitesi”, Taraz şehrinde bulunan "M.H. Dulati adındaki Taraz Devlet Üniversitesi”, "Taraz Devlet Pedagoji Üniversitesinde" eğitim görevlisi olan toplam 11 katılımcıdır. Katılımcıların cinsiyet, ünvan, yaş aralı̆̆ı, medeni durumu ve görev yeri ile ilgili bilgiler (Tablo 1'de) verilmiştir.

Tablo 1. Görüşme Katılımcıların İlişkin Demografik Bilgiler

\begin{tabular}{|c|c|c|c|c|c|}
\hline K.No & Cinsiyet & Unvan & $\begin{array}{c}\text { Yaş } \\
\text { Aralı̆ğ }\end{array}$ & $\begin{array}{l}\text { Medeni } \\
\text { Durum }\end{array}$ & Görev Yeri \\
\hline 1 & Kadın & $\begin{array}{l}\text { Tarih Bilimleri } \\
\text { Dr.Öğr. Üyesi, } \\
\text { Antropolog }\end{array}$ & 60 ve Üzeri & Evli & $\begin{array}{l}\text { Kazakistan Cumhuriyeti } \\
\text { Devlet Merkez Müzesi, }\end{array}$ \\
\hline 2 & Kadın & $\begin{array}{l}\text { Tarih Bilimleri } \\
\text { Doç.Dr. }\end{array}$ & $\begin{array}{c}40-49 \\
\text { Yaş Aras1 }\end{array}$ & Bekâr & Fakülte \\
\hline 3 & Kadın & Dr. PhD & $\begin{array}{c}50-59 \\
\text { Yaş Aras1 }\end{array}$ & Evli & $\begin{array}{c}\text { Kazakistan Cumhuriyeti Devlet Merkez } \\
\text { Müzesi, }\end{array}$ \\
\hline 4 & Kadın & $\begin{array}{l}\text { Tarih Bilimleri } \\
\text { Dr.Öğr. Üyesi, }\end{array}$ & $\begin{array}{c}40-49 \\
\text { Yaş Aras1 }\end{array}$ & Evli & $\begin{array}{l}\text { Kazakistan Cumhuriyeti Devlet Merkez } \\
\text { Müzesi, } \\
\text { Kazakistan Tarihi Araştırma Merkezi }\end{array}$ \\
\hline 5 & Erkek & Dr. PhD & $\begin{array}{c}40-49 \\
\text { Yaş Aras1 }\end{array}$ & Evli & Fakülte \\
\hline 6 & Kadın & Araştırma Görevlisi & $\begin{array}{c}30-39 \\
\text { Yaş Arası } \\
\end{array}$ & Evli & Fakülte \\
\hline 7 & Erkek & Araştırma Görevlisi & $\begin{array}{c}30-39 \\
\text { Yaş Aras1 }\end{array}$ & Evli & Multimedya Geleneksel Müzik Merkezi \\
\hline 8 & Kadın & Araştırma Görevlisi & $\begin{array}{c}30-39 \\
\text { Yaş Aras1 }\end{array}$ & Evli & Fakülte \\
\hline 9 & Kadın & Araştırma Görevlisi & $\begin{array}{c}40-49 \\
\text { Yaş Arası }\end{array}$ & Evli & Fakülte \\
\hline 10 & Kadın & $\begin{array}{l}\text { Tarih Bilimleri } \\
\text { Doç.Dr. }\end{array}$ & $\begin{array}{c}40-49 \\
\text { Yaş Aras1 }\end{array}$ & Evli & Fakülte \\
\hline 11 & Kadın & $\begin{array}{l}\text { Tarih Bilimleri } \\
\text { Doç.Dr. }\end{array}$ & $\begin{array}{c}40-49 \\
\text { Yaş Arası }\end{array}$ & Evli & Fakülte \\
\hline
\end{tabular}

Katılımcıların demografik bilgilerinden yaşları incelendiğinde 30 ve 60 yaş ve üzerinde olduğu görülmektedir. Katılımcıların \%27.27'si 30-39 yaş aralığındadır. \%54.5'i 40-49 yaş aralığındadır, \%9'1 50-59 yaş aralığındadır ve \%9'1 60 yaş ve üzerindedir. Cinsiyetine baktığımızda \%84.8'i yani katılımcıların dokuzu kadın ve \%18.18'i yani iki katılımcının erkek olduğu anlaşılmaktadır. Katılımcıların farklı mesleklere sahip olduğu gösterilmektedir. Katılımcıların yedisi fakültede ve diğer ise iki katılımcının "Kazakistan Cumhuriyeti Devlet Merkez Müzesi", bir katılımcının "Multimedya Geleneksel Müzik Merkezi", bir katılımcının "Kazakistan Cumhuriyeti Devlet Merkez Müzesi" ve "Kazakistan Tarihi Araştırma Merkezinde" görev yapıldığı gözlenmektedir. Katılımcıların mesleki çeşitlilik açısından geniş bir yelpazede dağılım gösterdikleri görülebilir. Medeni durumuna baktığımızda on katılımcının yani \%90.9'u evli, bir katılımcının yani \%9'u bekar olduğunu anlaşılmaktadır. 
Görüşmeye katılan katılımcıların ünvan olarak iki Dr.PhD, üç Tarih Bilimler Doç.Dr., bir Tarih Bilimleri Dr.Öğr.Üyesi Antropolog, bir Tarih Bilimleri Dr.Öğr.Üyesi ve dört Araştırma Görevlisi gibi farklı ünvanlara sahip akademisyenler olduğu görülmektedir.

$\mathrm{Bu}$ bölümde, uzmanlara yapılan görüşme verilerinin analizi sonucunda elde edilen bulgular Tablo 2'de sunulmuştur.

Tablo 2. Görüşme Formu Bulguları

\begin{tabular}{|c|c|c|c|}
\hline $\begin{array}{l}\text { Soru } \\
\text { No }\end{array}$ & Açıklama & $\begin{array}{c}\text { Toplam } \\
\text { Görüş }\end{array}$ & Katılımcı No \\
\hline Soru 1 & \multicolumn{3}{|l|}{$\begin{array}{l}\text { Ulu İpek Yolu'nu, Batı ve Doğu'yu bağlayan bir } \\
\text { fenomen olarak kabul edebiliyor muyuz? }\end{array}$} \\
\hline & $\begin{array}{l}\text { Evet, Ulu İpek Yolu Batı ve Doğu'yu bağlayan } \\
\text { uluslararası ticari ve ekonomik, medeni, kültürel ve } \\
\text { diplomatik ilişkilerin gelişiminde çok büyük öneme sahip } \\
\text { olmuş bir köprüdür. Ayrıca Orta Asya, onun içinde } \\
\text { Kazakistan'ın çok yerinden geçen Ulu İpek Yolu büyük } \\
\text { bir kültürel mirasa sahiptır. Ülkemizin dunya'ya tanılmas, } \\
\text { turizminin gelişmesi, yeni projelerin gelişmesi gibi çok } \\
\text { önemli çalışmalar yürütülmektedir. }\end{array}$ & 11 & $1,2,3,4,5,6,7,8,9,10,11$ \\
\hline \multirow[t]{3}{*}{ Soru 2} & \multicolumn{3}{|l|}{$\begin{array}{l}\begin{array}{l}\text { Ulu İpek Yolu ne idi? hangi güzergâhlardan } \\
\text { oluşturuyordu? }\end{array} \\
\end{array}$} \\
\hline & $\begin{array}{l}\text { Orta Asya ülkelerinden Kazakistan, Özbekistan, } \\
\text { Afganistan, Kırgızistan, Tacikistan ve Türkmenistan } \\
\text { topraklarından geçmiştir. }\end{array}$ & 7 & $1,3,4,5,8,9,11$ \\
\hline & $\begin{array}{l}\text { Ulu İpek Yolu uzak Doğu'dan gelen ipek ve baharat } \\
\text { kervanlarının Batı'ya taşınması bizim bildiğimize göre } \\
\text { Çin'den başlayarak Avrupa'nın batısına ve kuzeyine kadar } \\
\text { uzanan ticaret yollarını oluşturmuş ve aynı zamanda deniz } \\
\text { yoluyla ürünler, Akdeniz kıysından Roma (İtalya) } \\
\text { limanlarına ve Avrupa'ya ulaşmıştır. }\end{array}$ & 4 & $2,6,7,10$ \\
\hline \multirow[t]{2}{*}{ Soru 3} & \multicolumn{3}{|l|}{$\begin{array}{l}\text { Ulu İpek Yolu Kazakistan topraklarından hangi } \\
\text { bölgelerinden geçiyordu? }\end{array}$} \\
\hline & $\begin{array}{l}\text { Ulu İpek Yolu'nun Kazakistan topraklarında hangi } \\
\text { bölgelerinden geçtiğine bakarsak: Sarısu Yolu - Otırar'dan } \\
\text { Ertis ve İşim'e gidilen yol; Han Yolu - Taraz'dan Atasu'ya } \\
\text { giden yol; Kuzey İli Yolu - Çingeldi'den Balkaş'a giden } \\
\text { yol. Çin'den başlayarak Avrupa'ya uzanan İpek Yolu'nun } \\
\text { Kazakistan topraklarından geçen bölümü Sayram } \\
\text { (İsfidcab), Türkistan (Yesi), Şevuldur (Otrar), Karatobe } \\
\text { (Sauran), Süt Kent, Sığanak, Cend, Özkent, Karaşı, } \\
\text { Asanas yollarıdır. }\end{array}$ & 11 & $1,2,3,4,5,6,7,8,9,10,11$ \\
\hline \multirow[t]{2}{*}{ Soru 4} & \multicolumn{3}{|l|}{$\begin{array}{l}\text { Ulu İpek Yolu'nun en görkemli yılları ve edilgen } \\
\text { zamanı kaçıncı yüzyıla aittir? }\end{array}$} \\
\hline & $\begin{array}{l}\text { 16. Yüzyıl Ulu İpek Yolu'nun önemini ve etkisini yitirdiği, } \\
\text { Ulu İpek Yolu'nun aktiften pasif pozisyon haline geldiği } \\
\text { dönemdir. }\end{array}$ & 11 & $1,2,3,4,5,6,7,8,9,10,11$ \\
\hline Soru 5 & $\begin{array}{l}\text { Ulu İpek Yolu'nun modern zamanda tekrardan } \\
\text { canlandırılması hakkında fikriniz? }\end{array}$ & & \\
\hline & $\begin{array}{l}\text { Merkezi Asya'yı, Akdeniz'le Çin'i, Doğu ile Batı'yı, } \\
\text { Güney ile Küzey'i birleştiren bir medeniyet paylaşım yolu }\end{array}$ & 7 & $3,4,5,7,8,9,10$ \\
\hline
\end{tabular}




\begin{tabular}{|c|c|c|c|}
\hline & $\begin{array}{l}\text { olan Ulu İpek Yolu yeni ekonomik ve siyasi firsatları da } \\
\text { beraberinde getirmektedir. Birlikte yaşama isteği ve } \\
\text { medeniyetler arası diyalog çerçevesinde İpek Yolu projesi } \\
\text { XXI. Yüzyılın en ehemmiyetli küresel projelerinden } \\
\text { biridir }\end{array}$ & & \\
\hline & $\begin{array}{l}\text { Ulu İpek Yolu'nun modern zamanda kervanlarla } \\
\text { gerçekleşecek ticareti canlandırmak yerine bu bölgede } \\
\text { ulaşım alt yapısını sağlamlaştırmak bölgelerin tarihi ve } \\
\text { sosyo-kültürel yapısını güçlendirerek kültür turizmi, inanç } \\
\text { turizmi geliştirmeye müteveccih olmalıdır. }\end{array}$ & 4 & $1,2,6,11$ \\
\hline$\underline{\text { Soru } 6}$ & \multicolumn{3}{|l|}{$\begin{array}{l}\text { Ulu İpek Yolu güzergâhlarında ilk üretilen ve ticareti } \\
\text { yapılan mallar nelerdi? }\end{array}$} \\
\hline & $\begin{array}{l}\text { İpek Yolu üzerinde adı söylendiği gibi en önemli ve en } \\
\text { kıymetli olan mal, ipektir. Aynı zamanda ipek ile çeşitli } \\
\text { baharatların, kıymetli taşlar, pahalı eşyalar, hammadde ve } \\
\text { kumaşların taşınmasını söyleyebiliriz. }\end{array}$ & 11 & $1,2,3,4,5,6,7,8,9,10,11$ \\
\hline$\underline{\text { Soru } 7}$ & \multicolumn{3}{|l|}{$\begin{array}{l}\text { Ulu İpek Yolu'yla yayılan dinler ve memleketlere etkisi } \\
\text { nasıldı? }\end{array}$} \\
\hline & $\begin{array}{l}\text { Ulu İpek Yolu vasıtasıyla dini fikirler de geniş ölçüde } \\
\text { yayıldı. Misyonerler ise kendi dinlerini denizlerin öte } \\
\text { yakasındaki ülkelere bile taşıdılar. Hindistan'dan Orta } \\
\text { Asya ve Doğu Türkistan üzerinden Çin'e Budizm geldi. } \\
\text { Suriye, İran ve Arabistan'dan önce Hıristiyan dini, daha } \\
\text { sonra İslam dini ulaşmıştır. }\end{array}$ & 8 & $1,2,3,4,7,8,10,11$ \\
\hline & $\begin{array}{l}\text { Ulu İpek Yolu'yla III. yüzyılda İran'da ortaya çıkan } \\
\text { Maniheizm dini de yayılmıştır. Bu din kısa zamanda } \\
\text { İtalya'dan Çin'e kadar yayılma imkânı buldu. VIII. } \\
\text { yüzyılın başında Maniheistlerin yüksek yönetiminin sarayı } \\
\text { Semerkant'ta bulunuyordu. Maniheizm dini Orta Asya'da } \\
\text { uzun süre yaşadı. Bu esnada, Buddizm'den Tanrı inancı, } \\
\text { terminolojisi ve din anlayışına kadar bir çok alanda } \\
\text { etkilendi. }\end{array}$ & 3 & $5,6,9$ \\
\hline$\underline{\text { Soru } 8}$ & \multicolumn{3}{|l|}{$\begin{array}{l}\text { Ulu İpek Yolu'nun kültürel, sosyo-ekonomik önemi } \\
\text { nelerdir? }\end{array}$} \\
\hline & $\begin{array}{l}\text { Ulu İpek Yolu tarihin en eski çağlarından beri bir çok } \\
\text { ülkelerin siyasi, sosyal, kültürel ve en çok ekonomik } \\
\text { hayatında önemli bir rolü olmuştur. Ve şimdiye kadar yani } \\
\text { asırlar boyunca devam ederek gelen büyük bir yoldur. Bu } \\
\text { yol tek ticaret yolu değil. Günümüze kadar da bu yol sanat } \\
\text { ve kültür yolu diye geçmektedir. İnsanların birbirlerini } \\
\text { tanımalarını, anlamalarını sağlayan bir sosyal yoldur. } \\
\text { Çünkü bu Ulu İpek Yolu sanat, edebiyat, destan, } \\
\text { etnografya, müzik, tarih ve medeniyetler yoludur. }\end{array}$ & 11 & $1,2,3,4,5,6,7,8,9,10,11$ \\
\hline$\underline{\text { Soru } 9}$ & \multicolumn{3}{|l|}{$\begin{array}{l}\text { "Ulu İpek Yolu" uluslararası en büyük ve en eski bir } \\
\text { ticaret yolu olduğunu nasıl açıklayabilirsiniz? Ve } \\
\text { uluslararası ilişkilere nasıl bir etkisi oldu? }\end{array}$} \\
\hline & $\begin{array}{l}\text { Ulu İpek Yolu uluslararası en büyük ve en eski bir yoludur. } \\
\text { İpek Yolu günümüzde medeniyetler arası iletişimi için } \\
\text { büyük bir barış umudunu doğurmuştur. Doğu ve Batı'nın } \\
\text { çatışmacı değil, uzlaşmacı yanını sembole eden Ulu İpek } \\
\text { Yolu modern uluslararası ilişkilerin araştırma konuları } \\
\text { arasında yer almıştır. }\end{array}$ & 11 & $1,2,3,4,5,6,7,8,9,10,11$ \\
\hline Soru 10 & \multicolumn{3}{|l|}{ "Bir Kuşak, Bir Yol” projesi hakkında fikriniz? } \\
\hline
\end{tabular}




\begin{tabular}{|c|c|c|c|}
\hline & $\begin{array}{l}\text { "Bir Kuşak, Bir Yol" (One Belt One Road-OBOR) projesi, } \\
\text { Çin Devlet Başkanı Şi Çinping tarafindan } 2013 \text { y1lında } \\
\text { ilan edildi. Proje, başta Asya-Avrupa hattındaki önemli } \\
\text { ekonomiler arasında bir ulaştırma altyapısı, ticaret ve } \\
\text { yatırım bağlantısın kurmayı amaçlamaktadır. Sonraki } \\
\text { vakitlerde küresel bir kapsama ulaşan projenin kara yolu } \\
\text { ve denizden iki önemli uluslararası ticaret güzergâhı } \\
\text { bulunuyor. Kuşak kısmını oluşturan "İek Yolu Ekonomik } \\
\text { Kuşağı" ve yol kısmını oluşturan "Deniz İpek Yolu". Bu } \\
\text { projede } 65 \text { ülke yer alıyor. Onun içinde Türkiye dahil. Bu } \\
\text { bölgeler: Orta Asya, Avrupa, Doğu Asya, Güneydoğu } \\
\text { Asya, Güney Asya, Ortadoğu ve Kuzey Afrika diye } \\
\text { sıralanıyor. }\end{array}$ & 11 & $1,2,3,4,5,6,7,8,9,10,11$ \\
\hline Soru 11 & \multicolumn{3}{|l|}{$\begin{array}{l}\text { Ulu İpek Yolu'nun dünya kültürün gelişmesine genel } \\
\text { hangi etkileri olmuştur? }\end{array}$} \\
\hline & $\begin{array}{l}\text { Ulu İpek Yolu'nun dünya kültürün gelişmesine onun } \\
\text { içinde Türk dünyası halklarının birliğini, bütünlüğünü } \\
\text { sağlayan kültürel bir yoldur. Aynı zamanda zengin } \\
\text { kültürel miras ve kültürel işbirliği daha fazla potansiyelere } \\
\text { sahiptır. Türk Dünyası kültürel olarak tanınması ve } \\
\text { kültürel alış veriş içerisinde, büyük bir medeniyet } \\
\text { içerisinde devam etmektedir. }\end{array}$ & 11 & $1,2,3,4,5,6,7,8,9,10,11$ \\
\hline
\end{tabular}

Tablo 2'de görüldüğü gibi “Ulu İpek Yolu'nu, Bat1 ve Doğu’yu bağlayan bir fenomen olarak kabul edebiliyor muyuz?" soruya uzmanların hepsi aynı "Evet, Ulu İpek Yolu Batı ve Doğu'yu bağlayan uluslararası ticari ve ekonomik, medeni, kültürel ve diplomatik ilişkilerin gelişiminde çok büyük öneme sahip olmuş bir köprüdür. Ayrıca Orta Asya onun içinde Kazakistan'ın çok yerinden geçen Ulu İpek Yolu, büyük bir kültürel mirasa sahiptir. Ülkemizin dunya'ya tanıtılması, turizminin gelişmesi, yeni projelerin gelişmesi gibi çok önemli çalışmalar yürütülmektedir" olarak cevap vermişlerdir. "Ulu İpek Yolu'nun ortaya çıkış tarihi nedir ve hangi güzergâhlardan oluşturuyordu?” soruya uzmanların 7'si “Orta Asya ülkelerinden Kazakistan, Özbekistan, Afganistan, Kırgızistan, Tacikistan ve Türkmenistan topraklarından geçmiştir" olarak cevaplamış, diğer 4'ü "Ulu İpek Yolu uzak Doğu'dan gelen ipek ve baharat kervanların Batı'ya taşınması bizim bildiğimize göre Çin'den başlayarak Avrupa' nın batı ve kuzeyine kadar uzanan ticaret yollarını oluşturmuştur. Ve aynı zamanda deniz yoluyla Akdeniz kıyısından Roma (İtalya) limanlarına ulaştırılan ürünler Avrupa'ya ulaşmıştır" olarak cevap vermişlerdir. Üçüncüsü olan "Ulu İpek Yolu Kazakistan topraklarından hangi bölgelerinden geçiyordu?" soruya uzmanların hepsi aynı "Ulu İpek Yolu'nun Kazakistan topraklarından hangi bölgelerinden geçtiğini bakarsak: Sarısu Yolu - Otırar'dan Ertis ve İşim'e gidilen yol; Han Yolu - Taraz'dan Atasu'ya giden yol; Kuzey İli Yolu - Çingeldi'den Balkaş'a giden yol. Çin' den başlayarak Avrupa'ya uzanan İpek Yolu'nun Kazakistan topraklarından geçen bölümü Sayram (İsfidcab), Türkistan (Yesi), Şevuldur (Otrar), Karatobe (Sauran), Süt Kent, Sığanak, Cend, Özkent, Karaşık, Asanas yollarıdır” diye cevap vermişlerdir. Beşinci "Ulu İpek Yolu'nun modern zamanda tekrardan canlandırılması hakkında fikriniz?" sorusuna uzmanların 7'si "Merkezi Asya'y1, Akdeniz'le Çin'i, Doğu ile Batı'yı, Güney ile Küzey'i birleştiren bir medeniyet paylaşım yolu olan Ulu İpek Yolu yeni ekonomik ve siyasi fursatları da beraberinde getirmektedir. Birlikte yaşama isteği ve medeniyetler arası diyalog çerçevesinde İpek Yolu projesi XXİ. Yüzyılın en ehemmiyetli küresel projelerinden biridir" olarak, 4'ü "Ulu İpek Yolu'nun modern zamanda kervenlarla gerçekleşecek ticareti canlandırmak yerine bu bölgede ulaşım alt yapısını sağlamlaştırmak bölgelerin tarihi ve 
sosyo-kültürel yapısını güçlendirerek kültür turizmi, inanç turizmi geliştirmeye müteveccih olmalıdır" diye cevap vermişlerdir.

Altıncı "Ulu İpek Yolu güzergâhlarında ilk üretilen ve ticareti yapılan mallar nelerdir?" sorusuna uzmanların hepsi aynı "İpek Yolu üzerinde adı söylendiği gibi en önemli ve en kıymetli olan mal o ipektir. Aynı zamanda ipek ile çeşitli baharatların, kıymetli taşlar, pahalı eşyalar, hammadde ve kumaşların taşınmasını söyleyebiliriz" olarak cevap vermişlerdir. Yedinci "Ulu İpek Yolu'yla yayılan dinler ve memleketlere etkisi nasıldı?" sorusuna uzmanların 8'i "Ulu İpek Yolu vasitasıyla dini fikirler de geniş ölçüde yayıldı. Misyonerler ise kendi dinlerini denizlerin öte yakasındaki ülkelere bile taşıdılar. Hindistan'dan Orta Asya ve Doğu Türkistan üzerinden Çin'e Budizm geldi. Suriye, İran ve Arabistan'dan önce Hıristiyan dini, daha sonra İslam dini ulaşmıştır" ve 3'ü "Ulu İpek Yolu'yla III. yüzyılda İran'da ortaya çıkan Maniheizm dini de yayılmıştır. Bu din kısa zamanda İtalya'dan Çin'e kadar yayılma imkânı buldu. VIII. yüzyılın başında Maniheistlerin yüksek yönetiminin sarayı Semerkant'ta bulunuyordu. Maniheizm dini Orta Asya'da uzun süre yaşadı. Bu esnada, Buddizm'den Tanrı inancı, terminolojisi ve din anlayışına kadar bir çok alanda etkilendi" olarak cevap vermişlerdir. “Ulu İpek Yolu'nun kültürel, sosyo-ekonomik önemi nelerdir?" olarak adlandırılan sekizinci soruya uzmanların hepsi "Ulu İpek Yolu tarihin en eski çağlarından beri bir çok ülkelerin siyasi, sosyal, kültürel ve en çok ekonomik hayatında önemli bir rolü olmuştur. Ve şimdiye kadar yani asırlar boyunca devam ederek gelen büyük bir yoldur. Bu yol tek ticaret yolu değil. Günümüze kadar da bu yol sanat ve kültür yolu diye geçmektedir. İnsanların birbirlerini tanımalarını, anlamalarını sağlayan bir sosyal yoldur. Çünkü bu Ulu İpek Yolu sanat, edebiyat, destan, etnografya, müzik, tarih ve medeniyetler yoludur" diye cevap vermişlerdir. Dokuzuncu "Ulu İpek Yolu" uluslararası en büyük ve en eski bir ticaret yolu olduğunu nasıl açıklayabilirsiniz? Ve uluslararası ilişkilere nasıl bir etkisi oldu?" sorusuna uzmanların hepsi aynı "Ulu İpek Yolu vasıtasıyla hem küresel ticaret ve uluslararası en büyük ve en eski bir yoludur. İpek Yolu günümüzde medeniyetler arası iletişimi için büyük bir barış umudunu doğurmuştur. Doğu ve Batı'nın çatışmacı değil, uzlaşmacı yanını sembole eden Ulu İpek Yolu modern uluslararası ilişkilerin araştırma konuları arasında yer almıştır" diye cevap vermişlerdir.

Onuncu "Bir Kuşak, Bir Yol” projesi hakkında fikriniz?" sorusuna uzmanların hepsi aynı "Bir Kuşak, Bir Yol" (One Belt One Road-OBOR) projesi, Çin Devlet Başkanı Şi Çinping tarafından 2013 yılında ilan edildi. Proje, başta Asya-Avrupa hattındaki önemli ekonomiler arasında bir ulaştırma altyapısı, ticaret ve yatırım bağlantısın kurmayı amaçlamaktadır. Sonraki vakitlerde küresel bir kapsama ulaşan projenin kara yolu ve denizden iki önemli uluslararası ticaret güzergâhı bulunuyor. Kuşak kısmını oluşturan “İpek Yolu Ekonomik Kuşağı” ve yol kısmını oluşturan "Deniz İpek Yolu”. Bu projede 65 ülke yer alıyor. Onun içinde Türkiye dâhil. Bu bölgeler: Orta Asya, Avrupa, Doğu Asya, Güneydoğu Asya, Güney Asya, Ortadoğu ve Kuzey Afrika diye sıralanıyor" diye cevap vermişlerdir. On birinci ve son "Ulu İpek Yolu'nun dünya kültürün gelişmesine genel hangi etkileri olmuştur?" sorusuna uzmanların hepsi aynı "Ulu İpek Yolu'nun dünya kültürün gelişmesine onun içinde Türk dünyası halklarının birliğini, bütünlüğünü sağlayan kültürel bir yoldur. Aynı zamanda zengin kültürel miras ve kültürel işbirliği potansiyellerine sahiptir. Türk Dünyasının kültürel olarak tanınması ve kültürel alış veriş içerisinde, büyük bir medeniyette devam etmektedir" diye cevap vermişlerdir.

$\mathrm{Bu}$ soruların cevaplarını incelediğimizde; hazırlanan sorulara katılımcıların hepsi olumlu, geniş bir türde açıklayarak ve benzer cevap vermişlerdir. Katılımcıların sorulara benzer cevap vermesi, bu soruların şu an ki zamanda güncel ve önemli olduğunu göstermektedir. Yeni İpek Yolu programı çerçevesinde yapılmakta olan bu çalışmalar, ülkelerarası ve uluslararası ilişkilerin gelişmesi 
bakımından iyi bir fırsat olmakla birlikte, ülkenin ekonomisine, turizmine, şehirleşmesine, kültürlerarası ilişkilerine ve bilime sağlayacağı katkılarından dolayı önemli sayılmaktadır.

Araştırmaya katılanların demografik özellikleri Tablo 3'de gösterilmiştir.

Tablo 3. Demografik Bulgular Tablosu

\begin{tabular}{|c|c|c|c|}
\hline \multicolumn{2}{|l|}{ Değişkenler } & Sıklık/f & Yüzde/\% \\
\hline \multirow{5}{*}{ Yaş } & 18-29 & 230 & 57,5 \\
\hline & $30-39$ & 70 & 17,5 \\
\hline & $40-49$ & 60 & 15,0 \\
\hline & $50-59$ & 22 & 5,5 \\
\hline & 60 ve üzeri & 18 & 4,5 \\
\hline \multirow[b]{2}{*}{ Cinsiyet } & Erkek & 126 & 31,5 \\
\hline & Kadın & 274 & 68,5 \\
\hline \multirow{2}{*}{$\begin{array}{c}\text { Medeni } \\
\text { Durumu }\end{array}$} & Evli & 215 & 53,8 \\
\hline & Bekâr & 185 & 46,3 \\
\hline \multirow{5}{*}{$\begin{array}{l}\text { Eğitim } \\
\text { Durumu }\end{array}$} & Orta öğretim & 38 & 9,5 \\
\hline & Lise & 61 & 15,3 \\
\hline & Önlisans & 26 & 6,5 \\
\hline & Lisans & 145 & 36,3 \\
\hline & Lisansüstü & 130 & 32,5 \\
\hline \multirow{6}{*}{ Mesleği } & Öğrenci & 230 & 57,5 \\
\hline & Memur & 97 & 24,3 \\
\hline & Ev Hanımı & 20 & 5,0 \\
\hline & Emekli & 18 & 4,5 \\
\hline & Özel Sektör & 35 & 8,8 \\
\hline & Diğer & 0 & 0 \\
\hline
\end{tabular}

Anket verileri sonucunda katılımcıların \%57,5'i gibi büyük bir kısmı 18-29 yaşları arasındadır ve \%17,5'i de 30-39 yaşlar arasındadır. \%15'i 40-49, \%5,5'i 50-59 yaşları arasında, \%4,5'i de 60 yaş üzerindedir. Cinsiyet farklılıkları açısından katılımcılar arasında sayısal olarak büyük bir fark görülmektedir. Katılımcıların 126'sı erkek yüzdelik olarak bakıldığında ise \%31,5; 274 ise kadın yüzdelik olarak \%68,5 olmak üzere toplamda 400 adet anket yapılmıştır.

Katılımcıların medeni durumlarına bakıldığında 215 tanesi evli iken 185 tanesi ise bekâr olduğu görülmektedir. Yapılan ankette medeni durum boş bırakılmamış ve tam oran alınmıștır. Yüzdelik olarak bakıldığında ise \%53,8'lik kısmı evli ve \%46,3'lük kısmı bekâr olduğu görülmektedir.

Anket çalıșması sonucunda Kazakistan' da yaşamakta olan katılımcıların eğitim durumuna baktığında $\% 9,5$ oranı orta öğretim, $\% 15,3$ oranı lise, $\% 6,5$ oranı ön lisans, $\% 36,3$ oranı lisans ve $\% 32,5$ oranı lisansüstü oldukları sonucuna varılmıștır. Bu verilerden de anlașıldığı üzere katılımcıların büyük bir çoğunluğu üniversite mezunudur. Yapılan araştırma sonucunda Kazakistan'ın yerel halkının mesleğine bakıldığ 1 zaman en yüksek oranın \%57,5 ile öğrenci olduğu ve en az oranı \%4,5 emekli olduğu görülmektedir. Bunun sonucuna bakıldığında katılımcıların çoğunlukla genç kesimden yani öğrenciler olduğu sonucuna varılmıştır. 


\section{Anket Analizinden Elde Edilen Bulgular}

$\mathrm{Bu}$ bölümde, yerel halka yapılan anket verilerinin analizi sonucunda elde edilen bulgular sunulmuştur. Katılımcıların, Kazakistan'daki İpek Yolu kültürel değerlerinin turizmin gelişmesine pozitif ve negatif bakışına yönelik tanımlayıcı istatistikler (frekans ve yüzde) aşağıda Tablo 4'de gösterilmektedir.

Tablo 4. Frekans Tablosu

\begin{tabular}{|c|c|c|c|}
\hline No & Sorular & $\mathbf{f}$ & $\%$ \\
\hline \multirow[t]{2}{*}{1} & \multirow{2}{*}{ Ulu İpek Yolu en eski bir ticaret yoludur } & 297 & 74,3 \\
\hline & & 3 & 0,8 \\
\hline \multirow[t]{2}{*}{2} & \multirow[t]{2}{*}{ Ulu İpek Yolu’na adını veren ürün ipek kumaştır } & 303 & 75,8 \\
\hline & & 97 & 24,3 \\
\hline \multirow[t]{2}{*}{3} & \multirow{2}{*}{ Ulu İpek Yolu Çin’den başliyordu } & 245 & 61,3 \\
\hline & & 36 & 9,0 \\
\hline \multirow[t]{2}{*}{4} & \multirow[t]{2}{*}{ Ulu İpek Yolu Kazakistan topraklarından geçmişti } & 383 & 95,8 \\
\hline & & 17 & 4,3 \\
\hline \multirow[t]{2}{*}{5} & \multirow{2}{*}{ Ulu İpek Yolu Türkiye topraklarından geçmişti } & 205 & 51,2 \\
\hline & & 7 & 1,8 \\
\hline \multirow[t]{2}{*}{6} & \multirow{2}{*}{ Bu ticaret yoluyla farklı dinler yayılmıştı } & 204 & 51,0 \\
\hline & & 78 & 19,5 \\
\hline \multirow[t]{2}{*}{7} & \multirow[t]{2}{*}{ Ulu İpek Yolu'nun ana ve ek yolları oluşmuştur } & 185 & 46,3 \\
\hline & & 9 & 2,3 \\
\hline \multirow[t]{2}{*}{8} & \multirow{2}{*}{ Ulu İpek Yolu Batı ve Doğu'yu bağlayan bir köprüdür } & 209 & 52,3 \\
\hline & & 85 & 21,3 \\
\hline \multirow[t]{2}{*}{9} & \multirow[t]{2}{*}{ Dünya turizminin gelişimi Ulu İpek Yolu'ndan başlamıştı } & 180 & 45,0 \\
\hline & & 5 & 1,3 \\
\hline \multirow[t]{2}{*}{10} & \multirow{2}{*}{ 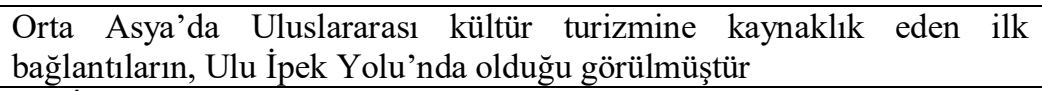 } & 302 & 75,5 \\
\hline & & 22 & 5,5 \\
\hline \multirow[t]{2}{*}{11} & \multirow{2}{*}{$\begin{array}{l}\text { Ulu İpek Yolu'nun Kazakistan topraklarında yer alan kültürel mirası, ülke } \\
\text { turizm gelişmesine katkı sağlayabilir }\end{array}$} & 247 & 61,8 \\
\hline & & 38 & 9,5 \\
\hline \multirow[t]{2}{*}{12} & \multirow[t]{2}{*}{ Ulu İpek Yolu'nda ipek altına eşitti } & 311 & 77,8 \\
\hline & & 16 & 4,0 \\
\hline \multirow[b]{2}{*}{13} & \multirow{2}{*}{$\begin{array}{l}\text { Ulu İpek Yolu; Güney Kazakistan ve Yedisu bölgesinin önemli } \\
\text { şehirlerden geçmekte olup, çevrelerinde değerli somut kültürel miraslar } \\
\text { bulunmaktadır }\end{array}$} & 325 & 81,3 \\
\hline & & 9 & 2,3 \\
\hline 14 & Ulu İpek Yolu'nun merkezlerinden biri olan Yesi kenti yani şimdiki & 366 & 91,5 \\
\hline & $\begin{array}{l}\text { Türkistan şehri, Hoca Ahmet Yesevi'nin türbesinin bulunduğu yerdir. } \\
\text { Burası, tüm müsülmanlarca bilinen bir inanç turizm destinasyonudur. }\end{array}$ & 5 & 1,3 \\
\hline 15 & Ulu İpek Yolu'nun önemli kısmının geçtiği yerde doğup ve yaşadığım için & 374 & 93,5 \\
\hline & çok şansliyım ve gurur duyuyorum & 26 & 6,5 \\
\hline 16 & Kazakistan'ın güney bölgesi benim için popüler bir turizm bölgesidir & 212 & 53,0 \\
\hline & & 9 & 2,3 \\
\hline 17 & Kazakistan topraklarından geçmiş Ulu İpek Yolu miraslarının, Kazakistan & 193 & 48,3 \\
\hline & turizminin gelişmesine katkısı olamaz & 2 & 0,5 \\
\hline 18 & İpek Yolu, kültür turizmine hitap etmektedir & 206 & 51,5 \\
\hline & & 20 & 5,0 \\
\hline 19 & "Bir Kuşak, Bir Yol" bir Kazakistan turizm projesidir & 204 & 51,0 \\
\hline & & 10 & 2,5 \\
\hline 20 & & 195 & 48,8 \\
\hline & buluntularının daha çok araştırılmasına ihtiyacı var & 58 & 14,5 \\
\hline Toplam & & 400 & 100 \\
\hline
\end{tabular}

July-2020 Vol:5 No:1 International Journal of Turkic World Tourism Studies 
1. "Ulu İpek Yolu en eski bir ticaret yoludur" diye soru cevabına en çok 297 kişi yani \%74,3'lük kısmı kesinlikle katılıyor ise 3 kişi katılmıyor olduğu görülmektedir.

2. "Ulu İpek Yolu'na adını veren ürün ipek kumaştır" diye ikinci soruya iki tane olumlu cevap görülmektedir. Katılımcıların 97'si yüzdelik oranı \%24,3'lük oranı katılıyor ise 303 kişi yüzdelik oranı \%75,8 kesinlikle katılıyor olduğu sonucu görülmektedir.

3. “Ulu İpek Yolu Çin'den başlıyordu” sorusuna 245 kişi yüzdelik oranı \%61,3'lük oranı katıllyor ise 119 kişi yüzdelik oranı \%29,8'lik oranı kesinlikle katılıyor ve 36 kişinin yüzdelik oranı \%9'luk oranı kararsız olduğu sonucuna varılmıştır.

4. "Ulu İpek Yolu Kazakistan topraklarından geçmişti” sorusuna yerel halkın olumlu cevap verdiğini görülmektedir. Katılımcıların 17 kişi yüzdelik oranı \%4,3'lük oranı katılıyor ise 383 kişinin yani $\% 95,8$ 'lik oranı kesinlikle katılıyor olduğu sonucuna varılmıştır.

5. "Ulu İpek Yolu Türkiye topraklarından geçmişti” sorusuna 205 kişi yüzdelik oranı $\% 51,2$ katıllyor, 134 kişi yüzdelik oranı \%33,5 kesinlikle katılıyor, 54 kişi yüzdelik oranı $\% 13,5$ kararsız ve olumsuz olarak 7 kişinin yüzdelik oranı \%1,8'lik katılmıyor cevabı sonucuna varılmıştır.

6. "Bu ticaret yoluyla farklı dinler yayılmıştı" diye sorusuna iki tane olumlu ve kararsızım diye üç cevaplar verilmiştir. Katılımcıların 204 kişi yüzdelik oranı \%51 katılıyor, 118 kişi yüzdelik oranı $\% 29,5$ kesinlikle katılıyor ve 78 kişi yüzdelik oranı \%19,5 kararsız olduğu görülmektedir.

7. “Ulu İpek Yolu'nun ana ve ek yolları oluşmuştur” sorusuna en çok 185 kişi yüzdelik oranı \%46,3 katılıyor ve en az ise 9 kişi yüzdelik oranı \%2,3 katılmıyor olduğu sonucuna varılmıştır.

8. "Ulu İpek Yolu Batı ve Doğu'yu bağlayan bir köprüdür” diye sorusuna 209 kişi yüzdelik oranı $\% 52,3$ kesinlikle katılıyor, 106 kişi yüzdelik oranı \%26,5 katılıyor ve 85 kişi yüzdelik oranı \%21,3 kararsız olduğu görülmektedir.

9. "Dünya turizminin gelişimi Ulu İpek Yolu'ndan başlamıştı" sorusuna katılımcıların 180 kişi yüzdelik oranı $\% 45$ kararsız, 132 kişi yüzdelik oranı \%33 katılıyor, 83 kişi yüzdelik oranı \%20,8 kesinlikle katılıyor ve 5 kişi yüzdelik oranı \%1,3 katılmıyor sonucu görülmektedir.

10. “Orta Asya'da Uluslararası kültür turizmine kaynaklık eden ilk bağlantıların, Ulu İpek Yolu'nda olduğu görülmüştür" sorusuna en çok 302 kişi yüzdelik oranı \%75,5'lik oranı katıllyor ve 22 kişi yüzdelik oranı $\% 5,5^{\prime}$ lik oranı kesinlikle katılıyor ve 76 kişi yüzdelik oranı $\% 19^{\prime}$ luk oranı kararsız olduğu sonucuna varılmıştır.

11. "Ulu İpek Yolu'nun Kazakistan topraklarında yer alan kültürel mirası, ülke turizm gelişmesine katk1 sağlayabilir" sorusuna 115 kişi yüzdelik oranı \%28,7'lik oranı katılıyor ve 247 kişi yüzdelik oranı \%61,8'lik oranı kesinlikle katılıyor ve 38 kişi yüzdelik oranı $\% 9,5$ 'lik oranı kararsız olduğu sonucuna varılmıştır.

12. "Ulu İpek Yolu'nda ipek altına eşitti” sorusuna 311 kişi yüzdelik oranı $\% 77,8$ 'lik oranı katılıyor ve 73 kişi yüzdelik oranı \%18,3'lük oranı kesinlikle katılıyor ve 16 kişi yüzdelik oranı \%4'lük oranı kararsız olduğu sonucuna varılmıştır.

13. "Ulu İpek Yolu; Güney Kazakistan ve Yedisu bölgesinin önemli şehirlerden geçmekte olup, çevrelerinde değerli somut kültürel miraslar bulunmaktadır" sorusuna 66 kişi yüzdelik oranı $\% 16,5^{\prime}$ lik oranı katılıyor ve 325 kişi yüzdelik oranı $\% 81,3^{\prime}$ lük oranı kesinlikle katılıyor ve 9 kişi yüzdelik oranı $\% 2,3$ 'lük oranı kararsız olduğu sonucuna varılmıştır. 
14. “Ulu İpek Yolu’nun merkezlerinden biri olan Yesi kenti yani şimdiki Türkistan şehri, Hoca Ahmet Yesevi'nin türbesinin bulunduğu yerdir. Buras1, tüm müsülmanlarca bilen bir inanç turizm destinasyonudur" sorusuna 29 kişi yüzdelik oranı \%7,2'lik oranı katılıyor ve 366 kişi yüzdelik oranı $\% 91,5^{\prime}$ lik oranı kesinlikle katılıyor ve 5 kişi yüzdelik oranı \%1,3'lük oranı kararsız olduğu sonucuna varılmıştır.

15. "Ulu İpek Yolu'nun önemli kısmının geçtiği yerde doğup ve yaşadığım için çok şanslıyım ve gurur duyuyorum" sorusuna 26 kişi yüzdelik oranı \%6,5'lik oranı katılıyor ve 374 kişi yüzdelik oranı $\% 93,5$ 'lik oranı kesinlikle katılıyor olduğu görülmektedir.

16. “Kazakistan'ın güney bölgesi benim için popüler bir turizm bölgesidir” sorusuna 212 kişi yüzdelik oranı \%53'lük oranı katıllyor ve 72 kişi yüzdelik oran $\% 18$ 'lik oranı kesinlikle katıllyor, 107 kişi yüzdelik oranu \%26,8'lik oranı kararsız ve 9 kişinin yüzdelik oranı $\% 2,3$ olduğu görülmektedir.

17. "Kazakistan topraklarından geçmiş Ulu İpek Yolu'n mirasları Kazakistan turizmin gelişmesine katkısı olamaz" sorusuna en çok olumsuz cevaplar verildiği görülmektedir. Toplam 400 kişinin 193 kişi yüzdelik oranı $\% 48,3$ 'lük oranı kesinlikle katılmıyor, 107 kişi yüzdelik oranı $\% 26,8$ 'lik oranı katılmıyor, 98 kişinin yüzdelik oranı $\% 24,5^{\prime}$ lik oranı kararsız ve 2 kişinin yüzdelik oranı $\% 0,5$ 'lik oranı katılıyor olduğu sonucuna varılmıştır.

18. "Ulu İpek Yolu, kültür turizmine hitap etmektedir” sorusuna 174 kişi yüzdelik oranı $\% 43,5$ 'lik oranı katılıyor, 20 kişinin yüzdelik oranı $\% 5$ ' lik oranı kararsız ve 206 kişinin yüzdelik oranı $\% 51,5$ 'lik oranı kesinlikle katılıyor olduğu sonucuna varılmıştır.

19. "Bir Kuşak, Bir Yol” bir Kazakistan turizm projesidir sorusuna 43 kişi yüzdelik oranı \%10,8'lik oranı katılıyor, 204 kişinin yüzdelik oran $1 \% 51$ 'lik oran 1 kararsız ve 10 kişinin yüzdelik oran $1 \% 2,5$ 'lik oranı kesinlikle katılıyor, 56 kişinin yüzdelik oranı \%14'lük oranı katılmıyor ve 87 kişini yüzdelik oranı \%21,8'lik oranı kesinlikle katılmıyor olduğu sonucuna varılmıştır.

20. "Güney Kazakistan bölgesinde turizmi geliştirmek için, Eski medeniyet buluntularının daha çok araştırılmasına ihtiyacı var" sorusuna 147 kişi yüzdelik oranı \%36,8'lik oranı katılıyor, 58 kişinin yüzdelik oranı $\% 14,5^{\prime}$ lik oranı kararsız ve 195 kişinin yüzdelik oranı $\% 48,8$ 'lik oranı kesinlikle katılıyor olduğu sonucuna varılmıştır.

\section{Kazakistan'daki İpek Yoluna Ait Kültürel Değerlerin Turizme Kazandırılması Pozitif Bakışına Yönelik Hipotezlere İliş kin Bulgular}

Katılımcıların, Kazakistan' daki İpek Yolu kültürel değerlerinin turizmin gelişmesine pozitif bakışa yönelik T test ve Anova analizleri aşağıda gösterilmektedir.

Tablo 5. Katılımcıların Yaşlarına Göre Kazakistan'daki Ulu İpek Yolu Kültürel Değerlerinin Turizmin Gelişmesine Yönelik Pozitif Bakış Varyans Analizi (Anova)

\begin{tabular}{|l|c|l|c|l|c|}
\hline & Kareler Toplamı & df & Kareler Ortalaması & f & Sig.(p) \\
\hline Gruplararası & 46,420 & 4 & 11,605 & 79,491 & 0,000 \\
\hline Gruplariçi & 57,667 & 395 & 0,146 & & \\
\hline Toplam & 104,086 & 399 & & & \\
\hline
\end{tabular}


Tablo 5 incelendiğinde katılımcıların Kazakistan'daki İpek Yolu kültürel değerlerinin turizmin gelişmesine pozitif bakış algıları yaş durumlarına göre farklılık gösterdiği ortaya çıkmaktadır $p<0,05$; $0,00<0,05$.

Tablo 6. Katılımcıların Kazakistan'daki İpek Yolu Kültürel Değerlerinin Turizmin Gelişmesine Yönelik Pozitif Bakışın Yaşlarına Göre Dağılımı

\begin{tabular}{|l|l|l|l|l|l|l|}
\hline Değişkenler & $\mathbf{N}$ & Ortalama & $\begin{array}{l}\text { Standart } \\
\text { Sapma }\end{array}$ & $\begin{array}{l}\text { Standart } \\
\text { Hata }\end{array}$ & Minimum & Maximum \\
\hline $\mathbf{1 8 - 2 9}$ yaş arası & 230 & 4,1522 & 0,50088 & 0,03303 & 2,67 & 4,67 \\
$\mathbf{3 0 - 3 9}$ yaş arası & 70 & 5,0000 & 0,00000 & 0,00000 & 5,00 & 5,00 \\
40-49 yaş arası & 60 & 4,6778 & 0,06034 & 0,00779 & 4,67 & 5,00 \\
50-59 yaş arası & 22 & 4,6667 & 0,00000 & 0,00000 & 4,67 & 4,67 \\
60 ve üzeri & 18 & 4,6667 & 0,00000 & 0,00000 & 4,67 & 4,67 \\
\hline Toplam & 400 & 4,4308 & 0,51075 & 0,02554 & 2,67 & 5,00 \\
\hline
\end{tabular}

Tablo 6 incelendiğinde katılımcıların yaşlarına göre Kazakistan' daki İpek Yolu kültürel değerlerinin turizmin gelişmesine yönelik pozitif bakışın ortalamaları 18-29 yaş Aralığının $(4,1522), 30-39$ yaş Aralığının (5), 40-49 yaş Aralığının (4,6778), 50-59 yaş Aralığının (4,6667), 60 üstü $(4,6667)$ olduğu görülmektedir. Bu durumda, $H_{l}$ "Araştırmaya katılanların yaşları ile pozitif bakışa ilişkin görüşleri arasında anlamlı bir farklılık vardır” hipotezi desteklenmektedir.

Tablo 7. Katılımcıların Cinsiyetlerine Göre Kazakistan'daki İpek Yolu Kültürel Değerlerinin Turizmin Gelişmesinin Pozitif Bakış Farkı (T test)

\begin{tabular}{|l|l|l|l|l|l|}
\hline & $\mathbf{N}$ & Ortalama & $\begin{array}{l}\text { Standart } \\
\text { Sapma }\end{array}$ & $\mathbf{t}$ & $\mathbf{p}$ \\
\hline Erkek & 126 & 4,4683 & 0,50978 & 0,994 & 0,032 \\
\hline Kadın & 274 & 4,4136 & 0,51121 & & \\
\hline
\end{tabular}

Tablo 7'de t testine göre araştırmaya katılan erkek (126) ve kadın (274) arasında $p<0,05 ; 0,03<0,05$ anlamlı bir farklılık göstermektedir. Bu durumda, $\mathrm{H}_{2}$ "Araştırmaya katılanların cinsiyetleri ile pozitif bakışa iliş̧kin görüşleri arasında anlamlı bir farklılık vardır” hipotezi desteklenmektedir.

Tablo 8. Katılımcıların Medeni Durumlarına Göre Kazakistan'daki İpek Yolu Kültürel Değerlerinin Turizmin Gelişmesinin Pozitif Bakış Farkı (T test)

\begin{tabular}{|l|l|l|l|l|l|}
\hline & $\mathbf{N}$ & Ortalama & $\begin{array}{l}\text { Standart } \\
\text { Sapma }\end{array}$ & $\mathbf{t}$ & $\mathbf{p}$ \\
\cline { 1 - 5 } Evli & 215 & 4,4124 & 0,52105 & $-0,778$ & 0,0437 \\
\cline { 1 - 4 } & 185 & 4,4523 & 0,49907 & & \\
\hline
\end{tabular}

Tablo 8'e göre araştırmaya katılanların evli (215) ve bekâr (185) arasındaki fark p<0,05;0,04<0,05 anlamlı bulunmuştur. $\mathrm{Bu}$ durumda, $\mathrm{H}_{3}$ "Araştırmaya katılanların medeni durum ile pozitif bakışa ilişkin görüşleri arasında anlamlı bir farklılık vardır" hipotezi desteklenmektedir. 
Tablo 9.Katılımcıların Eğitim Durumlarına Göre Kazakistan' daki İpek Yolu Kültürel Değerlerinin Turizmin Gelişmesine Yönelik Pozitif Bakıș Varyans Analizi (Anova)

\begin{tabular}{|l|l|l|l|l|l|}
\hline & Kareler Toplamı & df & Kareler Ortalaması & f & Sig.(p) \\
\hline Gruplararası & 0,853 & 4 & 0,213 & 0,816 & 0,041 \\
\hline Gruplariçi & 103,234 & 395 & 0,261 & & \\
\hline Toplam & 104,086 & 399 & & & \\
\hline
\end{tabular}

Tablo 9 incelendiğinde katılımcıların eğitim durumlarına göre Kazakistan'daki Ulu İpek Yolu kültürel değerlerinin turizmin gelişmesinin pozitif bakışlarında farklılık gösterdiği ortaya çıkmaktadır $\mathrm{p}<0,05 ; 0,04<0,05$.

Tablo10. Katılımcıların Kazakistan'daki İpek Yolu Kültürel Değerlerinin Turizmin Gelişmesinin Pozitif Bakışlarına Yönelik Görüşlerinin Eğitim Durumlarına Göre Dağılımı

\begin{tabular}{|l|l|l|l|l|l|l|}
\hline Değişkenler & $\mathbf{N}$ & Ortalama & $\begin{array}{l}\text { Standart } \\
\text { Sapma }\end{array}$ & $\begin{array}{l}\text { Standart } \\
\text { Hata }\end{array}$ & Minimum & Maximum \\
\hline Orta öğretim & 38 & 4,2895 & 0,62563 & 0,10149 & 2,67 & 5,00 \\
Lise & 61 & 4,4536 & 0,54783 & 0,07014 & 2,67 & 5,00 \\
Ön lisans & 26 & 4,4615 & 0,63300 & 0,12414 & 2,67 & 5,00 \\
Lisans & 145 & 4,4414 & 0,47933 & 0,03981 & 2,67 & 5,00 \\
Lisansüstü & 130 & 4,4436 & 0,46290 & 0,04060 & 3,00 & 5,00 \\
\hline Toplam & 400 & 4,4308 & 0,51075 & 0,02554 & 2,67 & 5,00 \\
\hline
\end{tabular}

Tablo 10'da katılımcıların eğitim durumlarına göre Kazakistan'daki İpek Yolu kültürel değerlerinin turizmin gelişmesinin pozitif bakışlar ortalamaları orta öğretim mezunlarının $(4,2895)$, lise mezunlarının (4,4536), önlisans mezunlarının $(4,4615)$, lisans mezunlarının $(4,4414)$ ve lisansüstü mezunlarının $(4,4436)$ olduğu görülmektedir. Önlisans mezunlarının pozitif bakışa ilişkin daha olumlu olduğu, orta öğretim mezunlarının daha olumsuz görüşte oldukları ifade edilebilirler. $\mathrm{Bu}$ durumda, $H_{4}$ : "Araştırmaya katılanların eğitim durumları ile pozitif baklşa ilişkin görüşleri arasında anlamlı bir farklılık vardır" hipotezi desteklenmektedir.

Tablo 11. Katılımcıların Mesleğine Göre Kazakistan'daki İpek Yolu Kültürel Değerlerinin Turizmin Gelişmesinin Pozitif Bakışına Yönelik Varyans Analizi (Anova)

\begin{tabular}{|l|l|l|l|l|l|}
\hline & Kareler Toplamı & df & Kareler Ortalaması & f & Sig.(p) \\
\hline Gruplararası & 46,529 & 4 & 11,632 & 79,829 & 0,000 \\
\hline Gruplariçi & 57,557 & 395 & 0,146 & & \\
\hline Toplam & 104,086 & 399 & & & \\
\hline
\end{tabular}

Tablo 11 incelendiğinde katılımcıların mesliğine göre Kazakistan'daki İpek Yolu kültürel değerlerinin turizmin gelişmesinin pozitif bakışlarında farklılık gösterdiği ortaya çıkmaktadır $\mathrm{p}<0,05$; $0,00<0,05$. 
Tablo 12. Katılımcıların Kazakistan'daki İpek Yolu Kültürel Değerlerinin Turizmin Gelişmesinin Pozitif Bakışına Yönelik Görüşlerin Mesleğe Göre Dağılımı

\begin{tabular}{|l|l|l|l|l|l|l|}
\hline Değişkenler & $\mathbf{N}$ & Ortalama & $\begin{array}{l}\text { Standart } \\
\text { Sapma }\end{array}$ & $\begin{array}{l}\text { Standart } \\
\text { Hata }\end{array}$ & Minimum & Maximum \\
\hline Öğrenci & 230 & 4,1522 & 0,50088 & 0,03303 & 2,67 & 4,67 \\
Memur & 97 & 4,6667 & 0,00000 & 0,00000 & 4,67 & 4,67 \\
Ev hanımı & 20 & 4,9833 & 0,07454 & 0,01667 & 4,67 & 5,00 \\
Emekli & 18 & 5,0000 & 0,00000 & 0,00000 & 5,00 & 5,00 \\
Özel sektör & 35 & 5,0000 & 0,00000 & 0,00000 & 5,00 & 5,00 \\
\hline Toplam & 400 & 4,4308 & 0,51075 & 0,02554 & 2,67 & 5,00 \\
\hline
\end{tabular}

Tablo 12 incelendiğinde katılımcıların mesleğine göre Kazakistan'daki İpek Yolu kültürel değerlerinin turizmin gelişmesinin pozitif bakışı ortalamaları öğrenci $(4,1522)$, memur $(4,6667)$, ev hanımı (4,9833), emekli (5) ve özel sektör (5) olduğu görülmektedir. Bu durumda, $\mathrm{H}_{5}$ "Araştırmaya katılanların mesleği ile pozitif bakışa ilişkin görüşleri arasında anlamlı bir farklılık vardır” hipotezi desteklenmektedir.

\section{Kazakistan'daki Ulu İpek Yolu Kültürel Değerlerinin Turizmin Gelişmesine Negatif Bakışına Yönelik Hipotezlere İlişkin Bulgular}

Katılımcıların, Kazakistan'daki İpek Yolu kültürel değerlerinin turizmin gelişmesine bir negatif bakışa yönelik T test ve Anova analizleri aşağıda gösterilmektedir.

Tablo 13. Katılımcıların Yaşlarına Göre Kazakistan' daki İpek Yolu Kültürel Değerlerinin Turizmin Gelişmesine Yönelik Negatif Bakış Varyans Analizi (Anova)

\begin{tabular}{|l|l|l|l|l|l|}
\hline & Kareler Toplamı & df & Kareler Ortalaması & f & Sig.(p) \\
\hline Gruplararası & 169,959 & 4 & 42,490 & 359,248 & 0,000 \\
\hline Gruplariçi & 46,718 & 395 & 0,118 & & \\
\hline Toplam & 216,678 & 399 & & & \\
\hline
\end{tabular}

Tablo 13 incelendiğinde katılımcıların Kazakistan' daki Ulu İpek Yolu kültürel değerlerinin turizmin gelişmesine negetif bakış algıları yaş durumlarına göre farklılık gösterdiği ortaya çıkmaktadır $p<0,05$, $0,00<0,05$.

Tablo 14. Katılımcıların Kazakistan’daki Ulu İpek Yolu Kültürel Değerlerinin Turizmin Gelişmesine Yönelik Negatif Bakışın Yaşlarına Göre Dağılımı

\begin{tabular}{|l|l|l|l|l|l|l|}
\hline Değişkenler & $\mathbf{N}$ & Ortalama & $\begin{array}{l}\text { Standart } \\
\text { Sapma }\end{array}$ & $\begin{array}{l}\text { Standart } \\
\text { Hata }\end{array}$ & Minimum & Maximum \\
\hline $\mathbf{1 8 - 2 9}$ yaş arası & 230 & 2,5087 & 0,43071 & 0,02840 & 2,00 & 3,50 \\
$\mathbf{3 0 - 3 9}$ yaş arası & 70 & 4,0143 & 0,08390 & 0,01003 & 4,00 & 4,50 \\
$\mathbf{4 0 - 4 9}$ yaş arası & 60 & 3,7500 & 0,25211 & 0,03255 & 3,50 & 4,00 \\
$\mathbf{5 0 - 5 9}$ yaş arası & 22 & 3,5000 & 0,00000 & 0,00000 & 3,50 & 3,50 \\
60 ve üzeri & 18 & 3,5000 & 0,00000 & 0,00000 & 3,50 & 3,50 \\
\hline Toplam & 400 & 3,0575 & 0,73692 & 0,03685 & 2,00 & 4,50 \\
\hline
\end{tabular}


Tablo 14 incelendiğinde katılımcıların yaşlarına göre Kazakistan'daki Ulu İpek Yolu kültürel değerlerinin turizmin gelişmesine yönelik negatif bakışın ortalamaları 18-29 yaş Aralığının $(2,5087)$, 30-39 yaş Aralığının (4,0143), 40-49 yaş Aralığının (3,7500), 50-59 yaş Aralığının (3,5000), 60 üstü $(3,5000)$ olduğu görülmektedir. Bu durmda, $H_{6}$ "Araştırmaya katılanların yaşları ile negaitif bakışa ilişkin görüşleri arasında anlamlı bir farklılık vardır” hipotezi desteklenmektedir.

Tablo 15. Katılımcıların Cinsiyetlerine Göre Kazakistan'daki Ulu İpek Yolu Kültürel Değerlerinin Turizmin Gelişmesinin Negatif Bakış Farkı (T test)

\begin{tabular}{|l|l|l|l|l|l|}
\hline & $\mathbf{N}$ & Ortalama & $\begin{array}{l}\text { Standart } \\
\text { Sapma }\end{array}$ & $\mathbf{t}$ & $\mathbf{p}$ \\
\hline Erkek & 126 & 3,1389 & 0,75799 & 1,500 & 0,013 \\
\cline { 1 - 4 } Kadın & 274 & 3,0201 & 0,72536 & & \\
\hline
\end{tabular}

Tablo 15' de t testine göre araştırmaya katılan erkek (126) ve kadın (274) arasında p<0,05; 0,01<0,05 anlamlı bir farkl111k göstermektedir. Bu durumda, $\mathrm{H}_{7}$ "Araştırmaya katılanların cinsiyetleri ile negatif bakışa ilişskin görüşleri arasında anlamlı bir farklılık vardır” hipotezi desteklenmektedir.

Tablo 16. Katılımcıların Medeni Durumlarına Göre Kazakistan'daki İpek Yolu Kültürel Değerlerinin Turizmin Gelişmesinin Negatif Bakış Farkı (T test)

\begin{tabular}{|l|l|l|l|l|l|}
\hline & $\mathbf{N}$ & Ortalama & $\begin{array}{l}\text { Standart } \\
\text { Sapma }\end{array}$ & $\mathbf{t}$ & $\mathbf{p}$ \\
\cline { 1 - 5 } Evli & 215 & 3,0326 & 0,72914 & $-0,729$ & 0,046 \\
\hline Bekâr & 185 & 3,0865 & 0,74679 & & \\
\hline
\end{tabular}

Tablo 16'ya göre araştırmaya katılanların evli (215) ve bekâr (185) arasındaki fark p <0,05;0,04<0,05 anlamlı bulunmuştur. Bu durumda, $H_{8}$ "Araştırmaya katılanların medeni durum ile negatif bakışa ilişskin görüşleri arasında anlamlı bir farklılık vardır” hipotezi desteklenmektedir.

Tablo 17. Katılımcıların Eğitim Durumlarına Göre Kazakistan'daki İpek Yolu Kültürel Değerlerinin Turizmin Gelişmesine Yönelik Negatif Bakış Varyans Analizi (Anova)

\begin{tabular}{|l|l|l|l|l|l|}
\hline & Kareler Toplamı & df & Kareler Ortalaması & f & Sig.(p) \\
\hline Gruplararası & 2,967 & 4 & 0,742 & 1,371 & 0,024 \\
\hline Gruplariçi & 213,710 & 395 & 0,541 & & \\
\hline Toplam & 216,678 & 399 & & & \\
\hline
\end{tabular}

Tablo 17 incelendiğinde katılımcıların eğitim durumlarına göre Kazakistan'daki Ulu İpek Yolu kültürel değerlerinin turizmin gelişmesinin negatif bakışlarında farklılık gösterdiği ortaya çıkmaktadır $\mathrm{p}<0,05 ; 0,02<0,05$.

Tablo 18. Katılımcıların Kazakistan' daki Ulu İpek Yolu Kültürel Değerlerinin Turizmin Gelişme sinin Negatif Bakışlarına Yönelik Görüşlerinin Eğitim Durumlarına Göre Dağılımı

\begin{tabular}{|l|l|l|l|l|l|l|}
\hline Değişkenler & $\mathbf{N}$ & Ortalama & $\begin{array}{l}\text { Standart } \\
\text { Sapma }\end{array}$ & $\begin{array}{l}\text { Standart } \\
\text { Hata }\end{array}$ & Minimum & Maximum \\
\hline Orta öğretim & 38 & 2,9079 & 0,70572 & 0,11448 & 2,00 & 4,00 \\
Lise & 61 & 3,0820 & 0,75928 & 0,09722 & 2,00 & 4,00 \\
Ön lisans & 26 & 3,3269 & 0,73406 & 0,14396 & 2,00 & 4,00 \\
\hline
\end{tabular}

July-2020 Vol:5 No:1 International Journal of Turkic World Tourism Studies 


\begin{tabular}{|l|l|l|l|l|l|l|}
\hline Lisans & 145 & 3,0241 & 0,73440 & 0,06099 & 2,00 & 4,50 \\
Lisansüstü & 130 & 3,0731 & 0,73430 & 0,06440 & 2,00 & 4,00 \\
\hline Toplam & 400 & 3,0575 & 0,73692 & 0,03685 & 2,00 & 4,50 \\
\hline
\end{tabular}

Tablo 18'de katılımcıların eğitim durumlarına göre Kazakistan'daki İpek Yolu kültürel değerlerinin turizmin gelişmesinin negatif bakışlar ortalamaları orta öğretim mezunlarının (2,9079), lise mezunlarının $(3,0820)$, önlisans mezunlarının $(3,3269)$, lisans mezunlarının $(3,0241)$ ve lisansüstü mezunlarının $(3,0731)$ olduğu görülmektedir. Önlisans mezunlarının pozitif bakışa ilişkin daha olumlu olduğu, orta öğretim mezunlarının daha olumsuz görüşte oldukları ifade edilebiler. Bu durumda, $H_{9}$ : "Araştırmaya katılanların eğitim durumları ile negatif bakışa ilişkin görüşleri arasında anlamlı bir farklılık vardır” hipotezi desteklenmektedir.

Tablo 19. Katılımcıların Mesleğine Göre Kazakistan'daki İpek Yolu Kültürel Değerlerinin Turizmin Gelişmesinin Negatif Bakışına Yönelik Varyans Analizi (Anova)

\begin{tabular}{|l|l|l|l|l|l|}
\hline & Kareler Toplamı & df & Kareler Ortalaması & f & Sig.(p) \\
\hline Gruplararası & 168,879 & 4 & 42,420 & 348,901 & 0,000 \\
\hline Gruplariçi & 47,798 & 395 & 0,121 & & \\
\hline Toplam & 216,677 & 399 & & & \\
\hline
\end{tabular}

Tablo 19 incelendiğinde katılımcıların mesleğine göre Kazakistan'daki Ulu İpek Yolu kültürel değerlerinin turizmin gelişmesinin negatif bakışlarında farklılık gösterdiği ortaya çıkmaktadır $\mathrm{p}<0,05 ; 0,00<0,05$.

Tablo 20. Katılımcıların Kazakistan'daki İpek Yolu Kültürel Değerlerinin Turizmin Gelişmesinin Negatif Bakışına Yönelik Görüşlerin Mesleğe Göre Dağılımı

\begin{tabular}{|l|l|l|l|l|l|l|}
\hline Değişkenler & $\mathbf{N}$ & Ortalama & $\begin{array}{l}\text { Standart } \\
\text { Sapma }\end{array}$ & $\begin{array}{l}\text { Standart } \\
\text { Hata }\end{array}$ & Minimum & Maximum \\
\hline Öğrenci & 230 & 2,5087 & 0,43071 & 0,02840 & 2,00 & 3,50 \\
Memur & 97 & 3,6392 & 0,22526 & 0,02287 & 3,50 & 4,00 \\
Ev hanımı & 20 & 4,0000 & 0,00000 & 0,00000 & 4,00 & 4,00 \\
Emekli & 18 & 4,0556 & 0,16169 & 0,03811 & 4,00 & 4,50 \\
Özel sektör & 35 & 4,0000 & 0,00000 & 0,00000 & 4,00 & 4,00 \\
\hline Toplam & 400 & 3,0575 & 0,73692 & 0,03685 & 2,00 & 4,50 \\
\hline
\end{tabular}

Tablo 20 incelendiğinde katılımcıların mesleğine göre Kazakistan'daki Ulu İpek Yolu kültürel değerlerinin turizmin gelişmesinin negatif bakışı ortalamaları öğrenci $(2,5087)$, memur $(3,6392)$, ev hanımı (4), emekli $(4,0556)$ ve özel sektör (4) olduğu görülmektedir. Bu durumda, $H_{10}$ "Araştırmaya katılanların mesleği ile negatif bakışa ilişkin görüşleri arasında anlamlı bir farklılık vardır” hipotezi desteklenmektedir.

Yukarıda önceden belirtilen 10 hipotezin hepsi T testi ve Anova istatistikleri sonucunda olumlu çıkmıştır.

Kazakistan'daki İpek Yolu kültürel değerlerinin turizmin gelişmesine katkısı çerçevesinde yapılan araştırma sonucunda yerli halkın, uzman araştırmacı ve çalışanların görüşlerinden yararlanarak; nitel görüşme, nicel analiz olarak Frekans, $\mathrm{T}$ test ve Anova analizleri yapılmıştır. $\mathrm{Bu}$ analizlerin 
sonucunda, görüşme formuna 11 uzman araştırmacı ve anket uygulamasına ise 400 yerli halk iştirak etmiştir. Genel olarak bakıldığında, önceden belirlenmiş olan 10 hipotezin tamamının desteklendiği görülmektedir.

\section{Sonuç ve Öneriler}

Gerçekleştirilen analizler neticesinde ulaşılan bulgular; Kazakistan'da İpek yolu kültürel mirasına yönelik uluslararası turizmin geliştirilmesinin, ülkeye olumlu katkı sağlayacağına inanıldığını göstermektedir. Gerek görüşme yapılan uzmanlar, gerekse İpek yolu üzerindeki kadim şehirlerden biri olan Taraz da ikamet edenler, turizmin etkilerinin olumlu olacağına inanmaktadırlar. Uygulanan anketlere göre; yerel halkın, turizmin fayda ve zararları konusunda yeterli duyarlılığa sahip olduğu tespit edilmektedir. Sonuçlar, sınıflandırılarak değerlendirildiğinde ise; halk, pozitif yönlü en yüksek etkileşimin, özellikle İpek yolu turizmi ile atılacak adımlar neticesinde olacağını öngörmektedir. Bilindiği gibi, İpek yolu, küreselleşme sürecinde dünyanın yeniden ilgi odağı olmuştur. Bu yolun ana güzergâhı büyük oranda Türk kültür coğrafyası üzerinden geçmektedir. Dolayısıyla, bu alanda yapılacak her türlü proje, Türk Dünyasındaki yakınlaşmayı artıracaktır. Özellikle İpek Yolu turizmi ile atılacak adımlar, farklı devlet çatılarında ve farklı coğrafyalarda yaşayan Türk topluluklarının birbirini daha yakından tanımasına vesile olacaktır.

Genel değerlendirme sonuçlarına göre öneriler şu şekilde sıralanabilir:

- İpek yolu turizm potansiyelinin tanıtımı, tüm bu rotadan yararlanan ülkelerin işbirliğiyle yapilmalidir.

- $\mathrm{Bu}$ yol üzerinde ki halkta turizm bilinci oluşturularak turizm hareketine tüm güzergâh üzerindeki ülkelerin halklarının katılması ve pozitif düşünmesi sağlanmalıdır.

- Ekonomik kalkınma için; İpek yolu üzerinde ki ülkelerde, özellikle dünyada son zamanlarda yaygınlaşan kültürel mirasın turizmde değerlendirilmesi anlayışına uygun yatırım ve girişimler özendirilmelidir.

- İpek yolu üzerinde ki, doğa ve kültür miraslarının tespiti yapılarak koruma ve kullanma projeleri hazırlanmalıdır.

- Uluslararası iletişim ve ilişkiler, kamu yönetimlerince özendirilmeli, kontrollü olarak geliştirilmelidir.

- İpek yolunun turistik etkinlikleri, sürdürülebilirlik yaklaşımıyla ele alınmalıdır.

- Turistik tesisleşme için, kültürel çevreyle uyumlu geleneksel mimari tarz, benimsenmelidir.

- Doğal çevre korunmalı, olumsuz etkilere karşı tedbirler üretilmelidir.

- İpek yolu güzergâhı, modern rota işaretlemeleriyle tanıtıcı tabelalar ile düzenlenmelidir.

- İpek Yolu’nun güvenliği ve rehberlik hizmeti sağlanmalıdır.

\section{Kaynakça}

Ablayeva, A. (2013). Kazakistan Turizminde İpek Yolu'nun Yeri ve Önemi, Yüksek Lisans Tezi, İstanbul Üniversitesi Sosyal Bilimler Enstitüsü, İstanbul.

Amatbek, D. (2017). Yeni İpekyolu Projeleri Bağlamında Kazakistan'ın Politikası, Ankasam, Ankara

Artuç, S.(2014). İpek Yolu’ndaki Göç Haraketlerinin Türk Edebiyatına Yansımaları, Türk Yurdu Yayınları, 100, 201, Ankara.

Atasoy, F.(2012). Doğa, Kültür ve Tarih Turizminin Birliğe Katkısı, "İpek Yolu Üzerinde Türklüğün Kendisini Keşfi” Türk Ocakları Genel Merkezi "Dilde Fikirde İşte Birlik Sempozyumu” 3-4 Ekim 2012 Ankara.

July-2020 Vol:5 No:1 International Journal of Turkic World Tourism Studies 
Atasoy, F. (2014). Ipek Yolu’nda Türk Dünyası Ortak Kültür Mirası, Türk Yurdu Yayınları,100, 9-11, Ankara. Ayverdi, E. H. (1982). Avrupa'da Osmanlı Mimari Eserleri, İstanbul.

Baypakov, K. (1998). Srednevekove Goroda na Velikom Şelkovom Puti. Almatı: Ğılım Yay.

Budagov, B. ve Kurbanov, B. (2017). İpek Yolu ve Türk Dünyası,1. Uluslararası İpekyolu Akademik Çalışmalar Sempozyumu, Nevşehir.

Deniz, T.(2016). Yeni Umutların Işı̆̆ında Tarihi İpek Yolu Coğrafyası, Marmara Coğrafya Dergisi, Sayı:34,Temmuz, İstanbul.

Erkal, M. E.(1994). Etnik Tuzak, Genişletilmiş 4.Baskı, Turan Kültür Vakfi Yayınları, İstanbul.

Gülcan, B.(2016). Türk Dünyası Illişkilerinde Kritik Faktör Olarak Turizm, Yükselen İpek Yolu 1.Cilt, İpek Yolu'nda Ekonomi ve Turizm, Türk Yurdu Yayınları, Ankara.

Köse, F. ( 2012). İstanbul Halveti Tekkeleri, M. Ü. İlahiyat Fakültesi VakfiYayınları, İstanbul.

Kydyrali, D. (2014). Medeniyetler Diyalogu İnşasında İpek Yolu’nun Önemi. Türk Yurdu Yayınları, 107, Ankara.

Mammadov, H. (2014). Ulu İpek Yolu ve Medeniyetler Arası Diyalog, İstanbul Sabahattin Zaim Üniversitesi Yayınları, İstanbul.

Oktay, K.(2016). Organize İpekYolu Turları Üzerine Bir İnceleme, Yükselen İpek Yolu 1.Cilt, İpek Yolu'nda Ekonomi ve Turizm, Türk Yurdu Yayınları, Ankara.

Purtaş, F. (2014). İpek Yolu'nun Güvenliğinde Kültürel Diplomasinin Rolü ve TÜRKSOY. Türk Yurdu Yayınları, 100, Ankara.

Sayım, F. (2017). Sosyal Bilimlerde Araştırma ve Tez Yazım Yöntemleri, Konu Tespiti- Süreç Yönetimi- Tez Yazımı, Seçkin Yayıncılık, Ankara.

Tezer, H. (2016). 21. Asır'da İpek Yolu Ekonomileri ve Türk Dünyası'nın Ekonomik Gelişim Süreci. Türk Yurdu Yayınları, 107, Ankara.

Turan, O. (1969). Selçuklular Tarihi ve Türk-İslam Medeniyeti, Turan Neşriyat Yurdu, İstanbul.

Uspanova, B. (2017). Kazakistan'ın Turizm Potansiyeli ve Geliştirilebilir Turizm Çeşidi Olarak Kültür Turizminin İncelenmesi, Yüksek Lisans Tezi. Akdeniz Üniversitesi Sosyal Bilimler Enstitüsü, Antalya.

Yereli, B.A. (2014). Yeniden Canlanan İpek Yolu'nda Ekonomik Stratejiler. Türk Yurdu Yayınları, 100, Ankara.

Yesevi, İ. (2010). Türkistan Şehri Uluğ Türkistan'ın Kalbi. Yesevi Dergisi, 198, İstanbul.

Zeybek, N. Z.(1997). Türk Olmak, Ocak Yayınları, Ankara.

July-2020 Vol:5 No:1 International Journal of Turkic World Tourism Studies 